\title{
ESTIMATING THE FISCAL IMPULSE IN UKRAINE
}

\author{
ARTEM VDOVYCHENKOa * \\ aNational Bank of Ukraine \\ Email: artem.vdovychenko@bank.gov.ua
}

\begin{abstract}
This paper estimates the fiscal impulse for Ukraine following the methodology of the OECD, which disaggregates budget revenues and expenditures into categories that are driven by economic cycles. To estimate the fiscal impulse the author calculates both long-term and short-term elasticities of various budget items with respect to GDP. This approach allows the author (i) to identify the fiscal policy response to economic crises in Ukraine in 2008-2009 and in 2014, and (ii) to reveal those budget items that remain sensitive to the fluctuations in the business cycle. The fiscal policy response to the 2014 crisis is found to be significantly tighter than the response to the crisis of 2008-2009. In addition, corporate income tax shows the strongest response to economic cycles among budget revenue categories, while VAT has the greatest contribution to the cyclical component of Ukraine's budget balance.
\end{abstract}

JEL Codes E62, H3, H61, C22

Keywords fiscal stance, fiscal impulse, dynamic least squares, autoregressive distributed lag model

\section{INTRODUCTION}

The economic shocks that have hit Ukraine in recent years are having a direct impact on fiscal policy, which has tightened. The system of public finance itself has become the sphere for conducting a range of radical reforms aimed at raising the efficiency of tax administration and budget expenditures. Such rapid changes on the fiscal front raise the issue of evaluating fiscal policy itself and the nature of its economic impact.

The standard approach to fiscal policy assessment is to calculate the fiscal impulse - a measure of change in the budget deficit that is adjusted for the automatic effects of various economic processes. The fiscal impulse measure describes the nature of the government's discretionary fiscal policy, which may seek to stimulate the economy (a loose fiscal policy) or restrain it (a tight fiscal policy). Researchers calculate and use this fiscal policy indicator in economic studies so as to understand the links between fiscal policy and other variables, and to predict inflation, GDP growth, and sovereign debt. However, the fiscal impulse is an estimated value, which raises a number of theoretical and empirical issues regarding consistency in its estimation.

This study focuses on estimating the fiscal impulse for Ukraine to identify periods of tight and loose fiscal policy in the country and to gain additional insight into predicting future movements in other macroeconomic indicators. To demonstrate our results, we test the hypothesis that Ukraine's fiscal policy response to the economic crisis of 2014 was tighter than that in the crisis of 2008-2009.

This study estimates the fiscal impulse using OECD methodology (Bouthevillain et al., 2001). This approach pinpoints the budget's cyclical components with greater accuracy by disaggregating them. To compare and test the robustness of our results, we also apply the methodology that has long been used by the IMF (Heller et al., 1986). The calculations use quarterly data from 2004-2016, which allows the estimation of the cyclical component of the budget balance during the crises of 2008 and 2014, and the fiscal policy response to these crises. As data sources, we used budgetary statistics from the State Treasury Service of Ukraine and GDP data from the State Statistics Service of Ukraine. The first research contribution of this study is an estimation of the fiscal impulse for Ukraine, making it possible to identify the extent of the tightening of fiscal policy in various periods. The second contribution is an estimation of the elasticities of a set of budget categories with respect to GDP, so as to obtain insights into how various budget revenue and expenditure items influence the structural budget balance.

The paper's structure is as follows: section two reviews the fiscal impulse estimation literature and methodologies; section three outlines the approach we use to estimate the fiscal impulse; section four describes the statistical attributes of the data; section five presents the results, and the last section discusses the results and gives the conclusions.

\section{LITERATURE REVIEW: MAIN APPROACHES TO ESTIMATING FISCAL POLICY STANCE}

Problems in determining the magnitude of the fiscal impulse arise from the fact that the nominal budget balance is a misleading measure of fiscal policy, as this measure is influenced by economic cycle fluctuations (Bouthevillain et al., 2001). A simple view on the budget balance structure allows for the identification of a cyclical component, which emerges as a result of the actions of automatic stabilizers, and a trend that is an approximate indicator of the discretionary fiscal policy itself. The actions of the automatic stabilizers are triggered by the economic nature of certain categories of budget expenditures and revenues. Revenues 
from the value-added tax (VAT) increase as final consumption rises, the latter positively correlating with the phase of the economic cycle. Among public sector expenditures, the classic example is unemployment benefit payments, which rise in periods of economic downturn. We can thus observe an automatic response of tax receipts to economic fluctuations that are unconnected to the government's fiscal policy decisions. The action of automatic stabilizers may obscure the real state of affairs in fiscal policy and distort the decisions of the officials in charge. The conventional approach to preventing these distortions is to calculate the cyclically adjusted primary balance (CAPB), which includes a structural component and the unanticipated discretionary fiscal decisions of the government. The CAPB is also frequently referred to as the fiscal stance (FS). The fiscal impulse (FI) is obtained by taking the first differences of the FS and indicates the direction and extent of the change in fiscal policy against the previous period.

Gali and Perotti (2003) argue that the budget deficit can be represented as the sum of the cyclical and structural components. The cyclical (nondiscretionary) deficit varies as processes beyond the government's control take place: cyclical fluctuations in the level of employment and tax bases. Along with this, cyclical fluctuations mainly affect tax receipts, as tax bases are very frequently connected to the economic cycle. As for budget expenditure categories, an obvious link exists between unemployment benefits and economic cycles, with the former acting as automatic stabilizers. ${ }^{1}$ Public debt servicing payments can also be viewed as a part of the "nondiscretionary component", as the government has no influence on their magnitude in the current period.

The cyclically adjusted (discretionary) deficit is a budget deficit that corresponds to the economy's potential GDP. ${ }^{2}$ In the literature, this indicator is frequently referred to as the fiscal stance. The fiscal stance is conventionally broken down into two parts: structural (endogenous) and non-systemic (exogenous). The endogenous component is the systemic response of the government to current or anticipated economic events. In other words, unlike the cyclical component, this deficit is a consequence of a fiscal policy decision by the government, rather than a mechanical reaction to economic developments. The exogenous component contains random changes to fiscal policy that do not result from systemic government decisions, but rather arise from exogenous political events or extraordinary circumstances (elections, hostilities, etc.). As the fiscal impulse is obtained by taking the first differences of fiscal stance, estimating fiscal stance is the first step in replicating fiscal impulse dynamics.

One of the fiscal stance estimation approaches that we are familiar with is the model that was in use by the IMF for a certain period (Heller et al., 1986):

$$
\begin{gathered}
\mathrm{FB}_{\mathrm{t}}=\left(\mathrm{R}_{\mathrm{t}}-\mathrm{G}_{\mathrm{t}}\right) \\
\mathrm{FB}_{\mathrm{t}}=\left(\mathrm{r}_{0} \mathrm{Y}_{\mathrm{t}}^{*}-\mathrm{g}_{0} \mathrm{Y}_{\mathrm{t}}^{*}\right)-\left[\mathrm{r}_{0}\left(\mathrm{Y}_{\mathrm{t}}^{*}-\mathrm{Y}_{\mathrm{t}}\right)\right]-\mathrm{FS}_{\mathrm{t}}
\end{gathered}
$$

where $F B_{t}$ is the primary budget balance, $\mathrm{r}_{0}=\mathrm{R}_{0} / \mathrm{Y}_{0}$ is the ratio between budget revenues and base-year nominal
GDP, $\mathrm{g}_{0}=\left(\mathrm{G}_{0}-\mathrm{UIB}_{0}\right) / \mathrm{Y}_{0}$ is the ratio between primary budget expenditures and base-year nominal GDP, $U I B_{0}$ - are base-year unemployment insurance benefits, $Y_{t}$ is nominal GDP in year $t, Y_{t}^{*}$ is potential nominal GDP in year $t, R_{t}$ are budget revenues, $G_{t}$ are primary budget expenditures, and $F S_{t}$ is fiscal stance in year $t$. The base year is the period in which GDP was closest to its potential value. This approach assumes a unit nominal elasticity of budget revenues with respect to GDP and a unit elasticity of budget expenditures with respect to potential GDP, net of unemployment insurance benefits. Budget expenditures, apart from unemployment benefits, are thus assumed to be acyclic, and deviations in their growth rate from the growth rate of potential GDP are evidence of tight/loose discretionary fiscal policy. Budget revenues, in turn, are assumed to have a unit elasticity with respect to the cycle.

One drawback of this approach is that not all budget revenues are cyclical, and elasticity with respect to GDP does not equal one for all taxes. In fact, this elasticity is very often greater than one. Model (2) thus produces a fiscal stance indicator that includes the automatic response of a number of taxes to changes in output. Another downside is the assumption that unemployment benefits are cyclical, even though they are only partially cyclical, due to the so-called natural rate of unemployment. Model (2) identifies as a fiscal stance the indicator that contains, besides discretionary component, the "fiscal drag", which reflects the growth in the tax burden that occurs as output rises under progressive taxation (Schinasi and Lutz, 1991).

However, the IMF has already taken a new approach to estimate the CAPB. This approach adjusts budget expenditures for the impact of the GDP gap on social security payments, which grow during economic downturns. The IMF methodology also envisages a broader set of factors for which the budget balance has to be adjusted to separate out the discretionary component. These factors include asset price dynamics, price movements in global commodities markets, and changes in the structure of the economy. ${ }^{3}$ Making these adjustments allows the estimation of the structural budget balance (SBB), a fiscal policy measure that requires more complicated estimates than the CAPB, which we estimate in this paper. ${ }^{4}$

The approach of the European Commission is rather widespread among the studies on CAPB. This is the disaggregation-based approach to estimating the elasticity of budget revenues with respect to GDP and capturing the cyclical component of unemployment insurance benefits:

$$
B_{c, t} / Y_{t}=R_{t} / Y_{t} \varepsilon_{R, Y_{r}} \times y_{r, c, t}-\left(\overline{X^{u} / Y}\right) \varepsilon_{X^{U}, Y_{r}} \times y_{r, c, t},
$$

where $B_{c, t}$ is the cyclical fiscal balance, $Y_{t}$ is GDP, $R_{t}$ are budget revenues, $\varepsilon_{R, Y_{r}}$ is the elasticity of budget revenues with respect to output, $X_{t}^{U}$ are unemployment-related budget expenditures, $\overline{X^{u} / Y}$ is the mean for 1970-1994, a reference indicator that reflects a neutral value of the ratio between unemployment insurance benefits and GDP, $\varepsilon_{X^{U}, Y_{r}}$ is the elasticity of unemployment-related budget expenditures with respect to output, and $y_{r, c, t}$ is the real-GDP gap (Bouthevillain et al., 2001).

${ }^{1}$ Automatic stabilizers not always belong to the cyclical part of the budget. For instance, wages in the public sector are acyclic, but they are a stabilizer that supports demand in times of recession (Fatás, 2009).

${ }^{2}$ One can read more about the nature of the potential GDP level and its estimation using the Kalman filter used in this study at Nikolaichuk and Mariiko (2007) and the NBU (2016).

${ }^{3}$ For more on the logic and technical aspects of this adjustment, see Bornhorst et al., (2011). 
The OECD approach extends Model (3) by further disaggregating budget expenditures and by estimating the elasticities of major tax receipts with respect to GDP, and the respective elasticity of unemployment benefits:

$$
\begin{gathered}
\mathrm{B}_{\mathrm{c}, \mathrm{t}} / \mathrm{Y}_{\mathrm{t}}=\sum_{\mathrm{j}} \mathrm{R}_{\mathrm{t}}^{\mathrm{j}} / \mathrm{Y}_{\mathrm{t}} \times \varepsilon_{\mathrm{R}^{\mathrm{j}, \mathrm{V}^{j}}} \times \varepsilon_{\mathrm{V}^{\mathrm{j}}, \mathrm{Y}_{\mathrm{r}}} \mathrm{y}_{\mathrm{r}, \mathrm{c}, \mathrm{t}}- \\
-\mathrm{X}_{\mathrm{t}}^{\mathrm{U}} / \mathrm{Y}_{\mathrm{t}} \times \varepsilon_{\mathrm{X}^{\mathrm{U}}, \mathrm{U}} \times \varepsilon_{\mathrm{u}, \mathrm{Y}_{\mathrm{r}}} \times \mathrm{y}_{\mathrm{r}, \mathrm{c}, \mathrm{t}},
\end{gathered}
$$

where $B_{c, t}$ is the cyclical fiscal balance, $Y_{t}$ is GDP, $R_{t}^{j}$ is a budget revenue item, $\varepsilon_{R^{j}, V^{j}}$ is the elasticity of budget revenues with respect to the relevant macroeconomic base $V_{i}, \varepsilon_{V^{j}, Y_{r}}$ is the elasticity of the macroeconomic base with respect to real GDP, $U$ is the number of unemployed, $X_{t}^{U}$ are unemploymentrelated budget expenditures, and $y_{r, c, t}$ is the real-GDP gap.

The distinguishing feature of the model (4) is its use of cross-elasticities, as it first calculates the elasticities of the relevant tax bases with respect to GDP, and then the elasticities of the relevant budget revenues with respect to the tax bases. Overall, the OECD approach comes closer to removing all automatic responses from the primary budget balance, as the elasticities of cyclical budget components can be greater than one. The IMF approach (Heller et al., 1986), which specifically applies to fiscal stance estimation based on primary-balance calculations, is easy to use and requires less detailed data, at the expense of lower accuracy. Model (4), by contrast, returns more accurate estimates and has higher data requirements (van den Noord, 2000; Girouard and André, 2005; Larch and Turrini, 2009).

Bouthevillain et. al. suggest an augmented version of model (4) (2001):

$$
\begin{gathered}
\mathrm{B}_{\mathrm{c}, \mathrm{t}} / \mathrm{Y}_{\mathrm{t}}=\sum_{\mathrm{j}} \mathrm{R}_{\mathrm{t}}^{\mathrm{j}} / \mathrm{Y}_{\mathrm{t}} \times \varepsilon_{\mathrm{R}^{\mathrm{j}}, \mathrm{v}^{\mathrm{j}}} \times \mathrm{v}_{\mathrm{c}, \mathrm{t}}^{\mathrm{j}}-\mathrm{X}_{\mathrm{t}}^{\mathrm{U}} / \mathrm{Y}_{\mathrm{t}} \times \varepsilon_{\mathrm{X}^{\mathrm{U}}, \mathrm{U}} \times \mathrm{u}_{\mathrm{c}, \mathrm{t}}- \\
-\mathrm{X}_{\mathrm{t}}^{\mathrm{G}} / \mathrm{Y}_{\mathrm{t}} \times \varepsilon_{\omega_{\mathrm{g}, \omega_{\mathrm{p}}}} \times \omega_{\mathrm{p}, \mathrm{c}, \mathrm{t}}
\end{gathered}
$$

where $B_{c, t}$ is the cyclical fiscal balance, $Y_{t}$ is GDP, $R_{t}^{j}$ is a budget revenue item, $\varepsilon_{R^{j}, v^{j}}$ is the elasticity of budget revenues with respect to the relevant macroeconomic base $\left(V_{j}\right), v_{c, t}^{j} u_{c, t}$, $\omega_{p, c, t}$, are values cyclical with respect to GDP, $U$ is the number of unemployed, $X_{t}^{U}$ are unemployment-related budget expenditures, $X_{t}^{G}$ - are public sector wages, and $\omega_{g^{\prime}} \omega_{p}$ are the average real wages in the public and private sectors.

The peculiarity of the model (5) is that it suggests removing the cyclical component of public sector wages from expenditures. The authors assume that public sector wages indirectly depend on cyclical output, due to their connection to the level of wages in the private sector. Real wages in the private sector are positively correlated with fluctuations in output, while public sector wages react to changes in private sector wages. The reliability of these assumptions depends on the wages system in place in a given country. The presence of automatic indexation of public sector wages makes this expenditure category elastic with respect to output.

The use of disaggregation approaches in estimating the fiscal stance requires the estimation of a range of elasticities of budget revenues and expenditures with respect to GDP. To estimate dynamic elasticities, Koester and Priesmeier (2012) suggest an approach that accounts for the presence of cointegration between taxes and the relevant tax base.
As the existence of a long-term cointegration relationship between taxes and relevant tax bases or GDP is, in theory, rather obvious, the authors have proposed a two-stage procedure for estimating long-term and short-term elasticities. With this approach, the authors estimate a cointegration equation (6) and an equation with short-term relationships which contains error-correction component (7):

$$
\begin{gathered}
\mathrm{T}_{\mathrm{t}}^{\mathrm{r}}=\beta_{1}^{\mathrm{r}} \mathrm{X}_{\mathrm{t}}^{\mathrm{r}}+\sum_{\mathrm{n}=1}^{\mathrm{N}} \gamma_{\mathrm{n}}^{\mathrm{r}} \mathrm{D}_{\mathrm{n}, \mathrm{t}}^{\mathrm{r}}+\sum_{\mathrm{i}=1}^{\mathrm{I}} \gamma_{\mathrm{i}}^{\mathrm{r}} \mathrm{S}_{\mathrm{i}, \mathrm{t}}^{\mathrm{r}}+\varepsilon_{\mathrm{t}}^{\mathrm{r}} \\
\Delta \mathrm{T}_{\mathrm{t}}^{\mathrm{r}}=\alpha_{0}^{\mathrm{r}}+\sum_{\mathrm{i}=1}^{\mathrm{I}} \pi_{\mathrm{i}}^{\mathrm{r}} S_{\mathrm{i}, \mathrm{t}}^{\mathrm{r}}+\sum_{\mathrm{n}=1}^{\mathrm{N}} \sum_{\mathrm{j}=0}^{\mathrm{q}} \alpha_{1 \mathrm{n}, \mathrm{j}} \Delta \mathrm{X}_{\mathrm{n}, \mathrm{t}-\mathrm{j}}^{\mathrm{r}}+\sum_{\mathrm{i}=1}^{\mathrm{p}} \alpha_{2, \mathrm{i}}^{\mathrm{r}} \Delta \mathrm{T}_{\mathrm{t}-\mathrm{i}}^{\mathrm{r}}+ \\
+\alpha_{3}^{\mathrm{r}} \varepsilon_{\mathrm{t}-1}^{\mathrm{r}}+\mathrm{u}_{\mathrm{t}}^{\mathrm{r}}
\end{gathered}
$$

where $T_{t}^{r}$ are receipts from the $r$ tax, $X_{t}^{r}$ is the tax base of the $r$ tax, $D_{n, t}^{r}$ are the potential deterministic components $n$ in the form of a constant, a linear trend, or a quadratic trend, $S_{i, t}^{r}$ are potential structural breaks in data in the form of impulses, shifts in levels, or changes in trends, $\varepsilon_{t}^{r}$ are stationary errors that denote deviations from the long-term equilibrium relationship, and $u_{t}^{r}$ are i.i.d. residuals. Of the parameters estimated in models (6) and (7), the one that interests us the most is $\beta_{1}{ }^{r}$ - the long-term elasticity of tax receipts with respect to the relevant base. The $\alpha_{1 n, j}$ coefficients, in turn, indicate short-term elasticity, the $\alpha_{2, i}^{r}$ coefficients indicate the persistence of the growth in tax receipts, while the $\alpha_{3}^{r}$ parameter measures the speed of convergence to the equilibrium relationship.

Unlike the long-term relationship between levels, the current impact of a change in the tax base on tax receipts is modeled as a simultaneous relationship among the growth rates of the variables under study (the $\alpha_{1 n, 0}$ coefficient in the model (7)). This coefficient is a conventional measure of the cyclicality of tax receipts (Koester and Priesmeier, 2012) and can be viewed as a direct short-term effect of tax base variation on tax receipts.

The dynamic nature of macroeconomic and fiscal variables, as well as the quantity of factors influencing them, justifies including lags of relevant variables into the model. This allows for the persistence of time series under analysis to be taken into account, mitigates the problems with the model's specification, and enables the removal of autocorrelation from errors.

Methods for estimating fiscal stance that are used in the literature vary by the degree of detail of budget categories that respond to cyclical economic fluctuations, and by their interpretations of the cyclical component of budget expenditures. Moreover, there is a certain consensus about the cyclicality of tax receipts, as the economic nature of the various types of taxes is approximately the same across all countries. However, country-specific features of public finances cause the discrepancies in interpretation of cyclicality of budget expenditures. In addition, fiscal stance estimation comes with a number of methodological issues related to endogeneity and the interpretation of the concept of discretionary fiscal policy.

\section{THE METHOD OF ESTIMATING FISCAL IMPULSE}

Figures $\mathrm{A} 1$ and $\mathrm{A} 2$ (in Appendix A) show the general fiscal policy trends in Ukraine. From the movements in the 
consolidated budget balance, it can be inferred that recent years have seen a rapid decline in Ukraine's budget deficit. Another observation that stands out is the widening of the gap between the nominal and primary budget deficits, especially when the hryvnia depreciates. The dynamics and structure of tax receipts (Figure A2) point to a gradual rise in the share of taxes in GDP, and a shift of the tax system away from direct taxes (the corporate income tax and individual income tax) towards indirect taxes (VAT, excise taxes, and import tariffs). The shift in fiscal policy priorities towards the taxation of consumption is manifested in the drop in the marginal rates of direct taxes. Corporate income tax, in particular, has been cut (Figure A3, in Appendix A). Individual income taxation was also simplified with the introduction in 2004 of the flat rate of the personal income tax, or PIT at a rather low level, which was then gradually raised. Meanwhile, the basic rate of VAT has stood at $20 \%$ without changing, excise taxes have been increased several times to resolve fiscal issues and bring their rates closer to European levels, and, on average, import tariffs have been cut as Ukraine has slowly integrated itself into global trade. The estimation of fiscal impulse assumes identification of these and other effects. Isolating the budget deficit impact of these and other discretionary changes in fiscal policy requires the fiscal impulse to be estimated.

As noted above, the fiscal impulse (FI) is obtained by taking the first differences of the fiscal stance (FS) and indicates the direction and extent of the change in fiscal policy from the previous period. In this study, we estimate the fiscal impulse in the form of the CAPB, which requires the calculation of the elasticities of certain budget categories with respect to GDP. For the purposes of this study, we use the OECD approach (4), which envisages estimating such elasticities and making relevant adjustments to the budget balance. This method yields more information on the cyclicality of budget items by extracting cyclical components from certain types of taxes and budget expenditures with higher accuracy. At the same time, we estimate direct elasticities, rather than cross-elasticities ${ }^{5}$ as suggested by the original methodology. Estimating the cross-elasticities involves using tax bases and generating relevant budget expenditures for the calculations. As a tax base, among others, usually, are used households' disposable income and unemployment. However, there are doubts about the consistency of these data, as during the period 2004-2016 in Ukraine had been multiple changes in the methodologies for calculating these variables.

Two aspects of our study are noteworthy. First, we use the OECD approach, as it is a more comprehensive method for estimating the CAPB and allows the cyclical components of the various categories of budget revenues and expenditures to be analyzed. Second, we compare our results to the simplified IMF approach to CAPB estimation (Heller et al., 1986), as the contemporary IMF methodology for identifying discretionary fiscal policy focuses on a somewhat different measure (SBB) and requires a different set of statistics and estimation methods.
In line with the standard methodology, we eliminate debt servicing payments from the calculations, as these payments do not count as discretionary decisions but rather constitute an obligation to pay for the government's past discretionary decisions. In theory, debt servicing payments are only partially dependent on the level of output, as they will not demonstrate cyclical fluctuations if their interest rates are fixed. ${ }^{6}$ Another factor that further complicates the separation of the cyclical component is the monetary policy response, which can manifest itself in the countercyclical dynamics of the central bank's key policy rate. The impact of the key policy rate on borrowing costs will cause the real effect of the output gap on debt servicing payments to be underestimated in periods of recession and overestimated when the economy overheats. This ambiguity in interpreting the essence of interest payments and their link to economic cycles has led to a consensus that these budget expenditures must be excluded from fiscal stance analysis. Another argument in favor of removing debt servicing payments from the analysis is that they can hardly be qualified as an economic stimulus.

What distinguishes our approach is that, in contrast to model (4), which assumes unemployment benefits are cyclical, we treat as cyclical expenditures to finance the deficit of the Pension Fund of Ukraine (PFU). Unemployment benefits in Ukraine are paid out by the extrabudgetary Fund for Obligatory State Social Insurance, which is not funded by the state budget. During economic downturns, this fund does not generate deficits that require budget financing, but rather reduces the financing of active measures that promote employment. However, the PFU regularly generates a deficit of its own budget, which is funded by the government, as the pension fund cannot make immediate spending cuts, as there is a need for pensions to be indexed to inflation. Since in Ukraine the financing to cover the PFU deficit comes from the state budget, and the level of real wages depends on the phase of the economic cycle, these expenditures can be regarded as cyclical.

To estimate regression equations with the relevant elasticities, we use two approaches: DOLS and ARDL. By comparing the estimated elasticities that these models yield, we can test the robustness of our results.

\subsection{DOLS}

The short-term and long-term elasticities are estimated using a two-stage procedure suggested by Engle and Granger (1987). Stage one estimates the long-term relationship (6) using the super-consistent dynamic ordinary least squares (DOLS) method outlined in Stock and Watson (1993). The approach consists of specifying a regression equation in which the tax receipt ${ }^{7}$ level is a dependent variable, while the tax base level for the same period, the current, past, and future values of the first differences of the tax base, deterministic components, and dummy variables denoting structural breaks in data are all explanatory variables.

${ }^{5}$ The elasticity of a certain tax/expenditure with respect to the respective base multiplied by the elasticity of the tax/expenditure base with respect to GDP

${ }^{6}$ Another argument is that interest payments should be taken out of calculations to minimize the impacts of inflation and the exchange rate on the budget balance. This reasoning is not sufficiently substantiated. Interest payments are indeed rather strongly correlated with the level of prices and exchange rate, but interpreting their exclusion as an adjustment of budget expenditures implies that budget revenues should be adjusted for the same factors. International trade taxes, for instance, are strongly related to exchange rate movements, but this fact is usually ignored when estimating fiscal stance.

7 In the case of tax receipts. 


$$
\begin{aligned}
T_{t}^{r}= & \beta_{1}^{r} X_{t}^{r}+\sum_{n=1}^{N} \gamma_{n}^{r} D_{n, t}^{r}+\sum_{i=1}^{I} \gamma_{i}^{r} S_{i, t}^{r}+ \\
& +\sum_{n=1}^{N} \sum_{j=-p}^{q} \alpha_{n, j} \Delta X_{n, t-j}^{r}+\varepsilon_{t}^{r}
\end{aligned}
$$

where $T_{t}^{r}$ are receipts from the $r$ tax, $X_{t}^{r}-$ is the tax base of the $\mathrm{r}$ tax, $D_{n, t}^{r}$ are the potential deterministic components $\mathrm{n}$ in the form of a constant, a linear trend, or a quadratic trend, $S_{i, t}^{r}$ are potential structural breaks in data in the form of impulses, shifts in levels, or changes in trends, $\varepsilon_{t}^{r}$ are stationary errors that denote deviations from the long-term equilibrium relationship.

Stock and Watson (1993) argue that the DOLS method is superior to OLS and Johansen's approach, especially for small samples, as DOLS accounts for orders of integration higher than the first order, and deals with the endogeneity and autocorrelation problem (Masih and Masih, 1999). Stage two employs a model that includes the short-term dynamics of (7) and deviations from, the equilibrium relationship obtained from the stage-one equation (8). ${ }^{8}$ To come close to the normal distribution and eliminate error autocorrelation, model (7) may be augmented to include lags in the dependent and independent variables. Considering the sample's limitations, we included only the statistically significant lagged variables in the final version of the model.

Applying DOLS to a small number of observations carries the risk of model overparameterization, as the number of lags and leads of an independent variable in the model (6) is usually determined on the basis of information criteria. This approach may result in too many variables being added to the model. To limit the number of parameters without losing too many observations, we chose to include no more than two lags and two leads of the tax base. ${ }^{9}$ Simultaneously, to adjust the results for potential error autocorrelation and heteroscedasticity, we used a heteroscedasticity adjusted variance-covariance matrix (Newey-West HAC matrix).

An approach similar to the one noted above was also employed by Dudine and Jalles (2017), who used Fully Modified Ordinary Least Squares (FMOLS) to model a long-term relationship between the tax base and GDP at the country level. Introduced by Phillips and Hansen (1990), this method involves a semiparametric adjustment to eliminate problems caused by the long-term correlation between deviations from the long-term relationship and the innovations in the stochastic process that follow every regressor.

To take into account the difficulties in identifying cointegration, we introduce into the long-term relationships a constant and a dependent variable. Accordingly, we treat all shocks as transitive and incorporate them as dummy variables into the short-term part of the regressions. For inferences about the statistical significance of the long-term relationships, we use the t-statistics of the explanatory variable in the long-term relationship $\left(\beta_{1}{ }^{r}\right.$ in (6)) and the loading coefficient in the error correction model $\left(\alpha_{3}^{r}\right.$ in (7)).

\subsection{ARDL}

As an alternative method for estimating the long-term and short-term elasticities of taxes with respect to GDP, we ran a set of autoregressions with distributed-lags (ARDL) of the following type:

$$
\begin{aligned}
\mathrm{y}_{\mathrm{t}}=\beta_{0}+ & \sum_{\mathrm{q}=1}^{\mathrm{Q}} \beta_{\mathrm{q}} \mathrm{y}_{\mathrm{t}-\mathrm{q}}+\sum_{\mathrm{n}=0}^{\mathrm{N}} \alpha_{\mathrm{n}} \mathrm{x}_{\mathrm{t}-\mathrm{n}}+ \\
& +\sum_{\mathrm{i}=1}^{\mathrm{I}} \mathrm{c}_{\mathrm{i}} \mathrm{D}_{\mathrm{i}}+\varepsilon_{\mathrm{t}},
\end{aligned}
$$

where $y_{t}$ is an endogenous variable, $x_{t}$ is an exogenous variable that may influence $y_{t}$ without a lag, and $D_{i}$ are deterministic variables that denote trends, structural breaks, and outliers in data.

This approach has a number of advantages over Johansen's method, which employs a vector error correction model (VECM). First, ARDL is better suited for identifying long-term relationships in small samples. VECM is a system of equations and, as such, requires a large number of observations. Second, unlike VECM, ARDL does not require variables to have the same level of integration. Under this approach, regression variables can be I(0) and/or I(1), which eliminates the issue of preliminary testing for stationarity (Pesaran et al., 2001). Specifying a cointegrating relationship under Johansen's approach requires statistical evidence that all of the model's variables are I(1). With short time series and frequent structural breaks in data, stationarity tests lose power significantly. Another serious drawback of the Johansen method is the sensitivity of the cointegration test to the model specification. Specifying VECM requires the choice of a number of endogenous and exogenous variables, the inclusion of deterministic components, and the selection of an optimal quantity of lags. By contrast, the ARDL model has greater flexibility, enabling the use of an optimal number of lags for every variable.

When specifying ARDL, we used the following algorithm:

- for every variable, we conducted unit-root tests to ensure that none of the variables are I(2);

- specifying ARDL in levels with an optimal number of lags basing on the Akaike information criterion (AIC);

- testing for normality and autocorrelation of the residuals;

- in case of detection non-normality or autocorrelation in residuals, the dummy variables and additional lags are included in the model;

- testing for the existence of a long-term relationship between variables (bounds test);

- if a long-term relationship is identified, we use it to calculate the long-term elasticities and estimate the parameters of the error correction model (ECM) - the short-term coefficients of elasticity and the coefficients of convergence;

\footnotetext{
${ }^{8}$ In doing so, we first adjusted the errors to account for the effect of the $\sum_{n=1}^{N} \sum_{j=-p}^{q} \alpha_{n, j} \Delta X_{n, t-j}^{r}$ component from equation (8), as the long-term relationship is expressed
as equation (6), while the actual estimation of its parameters is based on model (8).

${ }^{9}$ Under this approach, automatic responses between the tax base and tax receipts are assumed to take place within two quarters before and after a particular observation. This assumption is sufficiently realistic and applies to such restrictions (Koester and Priesmeier, 2012).
} 
- in the absence of a long-term relationship, the variables are transformed into stationary form, a separate ARDL is specified, and the short-term elasticities are estimated.

The bounds test assesses the probability that a long-term relationship exists between variables, regardless of whether they are I(0) or I(1). The critical values for the bounds test are presented in Pesaran et al. (2001), but they have asymptotic properties. For small samples of data, Narayan (2005) revised the critical values, and we use them in this paper, as our sample comprises no more than 60 observations.

If a long-term relationship between variables is identified, the long-term elasticities are estimated by running a regression based on model (10):

$$
\begin{gathered}
\Delta \mathrm{y}_{\mathrm{t}}=\beta_{0}+\sum_{\mathrm{q}=1}^{\mathrm{Q}} \beta_{\mathrm{q}} \Delta \mathrm{y}_{\mathrm{t}-\mathrm{q}}+\sum_{\mathrm{n}=0}^{\mathrm{N}} \alpha_{\mathrm{n}} \Delta \mathrm{x}_{\mathrm{t}-\mathrm{n}}+ \\
+\sum_{\mathrm{i}=1}^{\mathrm{I}} \mathrm{c}_{\mathrm{i}} \Delta \mathrm{D}_{\mathrm{i}}+\theta_{1} \mathrm{y}_{\mathrm{t}-1}+\theta_{2} \mathrm{x}_{\mathrm{t}-1}+\varepsilon_{\mathrm{t}}
\end{gathered}
$$

where the long-term coefficient equals $\left(-\theta_{2} / \theta_{1}\right)$.

The use of the two approaches to estimating the elasticities ensures the results are more robust. In addition, the proposed econometric models allow for the estimation of the difference between the short-term and long-term elasticities of various budget items with respect to GDP, as well as the rate of convergence of the models' variables to the equilibrium relationship.

\section{DATA TO ESTIMATE FISCAL IMPULSE}

Our estimation relies on quarterly GDP observations and data from Ukraine's consolidated budget for 2004-2016. ${ }^{10}$ The data were seasonally adjusted using the Census X12 algorithm. The data were also adjusted for 2010 prices using a GDP deflator and converted into logs. We did not perform the log transformation of PFU deficit financing, ${ }^{11}$ as these expenditures equaled zero in 2007-2008. We deleted debt service payments from budget expenditures. We calculated potential GDP using the Kalman filter. To obtain estimates using the OECD methodology, we calculate the long-term elasticities with respect to GDP for the following variables: personal income tax (PIT), corporate income tax (CIT), VAT, excise tax, import tariffs, and PFU deficit financing. ${ }^{12}$ The remaining budget revenue and expenditure categories are assumed to be acyclic, as no economic preconditions exist for them to respond automatically to GDP fluctuations.

Tables B1 and B2 (in Appendix B) present a preliminary analysis of log data with descriptive statistics and stationarity tests. The descriptive statistics indicate that the time series of PIT, CIT, VAT on imports, and PFU deficit financing are not normally distributed. Dickey-Fuller GLS and KPSS stationarity tests, with the addition of a constant, were conducted mainly to verify that none of the variables are I(2) processes. The tests are necessary for the consistent construction of the ARDL models that estimate the elasticities. The results of the Dickey-Fuller GLS test indicate that most variables are I(1), apart from excise tax receipts and PFU deficit financing, as these time series do not become stationary after their first differences are taken. The KPSS test returns results that largely confirm those of the Dickey-Fuller GLS test, the difference being that real GDP, gross domestic VAT, and the import tariffs are $I(0)^{13}$, while the excise tax is $I(1)$. The tests yield the overall inference that the time series of the excise tax and PFU deficit financing may be I(2). A visual analysis of movements in these variables shows there are structural breaks in the trends. The Unit Root with Break Test of the first differences of the excise tax and PFU deficit financing points to their stationarity when innovative outliers ${ }^{14}$ in the time series are controlled for (Figure A4, in Appendix A).

The confirmed stationarity, at least in first differences, of the data selected for the study, makes these data eligible for standard time series analysis. However, the time series of the excise tax and PFU deficit financing exemplify the importance of taking account of outliers and breaks when conducting an analysis involving special tests for stationarity.

\section{RESULTS OF ESTIMATIONS}

Table B3 (in Appendix B) presents the estimates of the long-term and short-term elasticities of major tax receipts with respect to GDP for Ukraine, and average estimates for OECD countries provided by Girouard and André (2005) and which are used by the IMF in the relevant estimations. Tables B4 and B5 (in Appendix B) contain more information on the parameters of the models used in the calculation of the elasticities and loading coefficients. The elasticities estimated using DOLS and ARDL are sufficiently close, except in the case of the domestic VAT. In both cases, the elasticity for domestic VAT is close to unity - a value that, in theory, must be manifested by all proportional taxes.

The results in Table 3 demonstrate that we have not been able to capture a statistically significant long-term relationship of GDP with PIT and the excise tax. In the case of the excise tax, the reason may be that this budget revenue item has a significant discretionary component. Excise tax rates are subject to constant revision, and this tax is, in essence, a manual tool for ensuring that budget revenues are received in full. Another reason is that the tax bases for this tax are sufficiently different (alcohol products, tobacco products, and energy) and vary in terms of their relationship with GDP dynamics. The analysis of movements in excise tax receipts and real GDP (Figure $A 5$, in Appendix $A$ ) indicates that the trends in these variables were negatively correlated with each other for a significant number of sample observations. In 2002-2008, excise tax receipts had been falling in real terms, despite the economy growing. Following the crisis of 2008-2009, the government was faced with the need to seek new funding sources, which resulted in excise tax rates being raised and remaining in line with GDP dynamics up until 2014. After the 2014 crisis, excise tax rates were radically revised again, and their growth began to outpace that of GDP.

${ }^{10}$ The resulting estimates might be somewhat skewed towards a tighter fiscal policy for $2014 \mathrm{H} 1$, as the Ukrainian statistics did not account for the GDP of Crimea and the non-government controlled areas of Donetsk and Luhansk oblasts, even though companies located there continued to pay a certain amount of taxes. We partially take account of that structural break in the data by using dummy variables in our regressions, but accurate estimates of tax receipts from government-controlled areas are hard to obtain.

${ }^{11}$ The sample period for these expenditures is 2005-2016.

${ }^{12}$ Data on budget revenues and expenditures was taken from the reports of the State Treasury Service of Ukraine (www.treasury.gov.ua/main/uk/publish/ category/23596).

${ }^{13}$ The discrepancy in the test results for these variables is not important, as the results primarily confirm that the variables are not I(2). 
The difficulties in identifying a long-term relationship between GDP and PIT arise from the fact that the growth of tax receipts was catching up with the growth rate of GDP in 2004-2008 after tax receipts plummeted in 2004 when there was a switch from a progressive tax rate to a flat one (13\%). This was related to the rapid growth in wages, driven in particular by an increase in the minimum wage. Since 2015, PIT tax receipts have been growing more rapidly than GDP (Figure A5), likely due to a higher tax rate. The existence of structural breaks in the PIT and a sharp turnaround in the direction of the trends do not provide statistical evidence sufficient to detect cointegration. The short-term elasticity of 0.7 differs significantly from the analogous average measures for OECD countries (except Slovakia, for which the estimated coefficient is also 0.7). This is attributable to the absence of progressive individual income taxes in Ukraine, and to a significant amount of individual incomes that are taxed on special terms, such as investment returns, business income, etc.

The high elasticities for CIT, VAT on imports, and import tariffs are notable. At the same time, the elasticities for import taxes significantly differ from the analogous coefficients for OECD countries. The high elasticities indicate that the taxes produce excessive responses to the relevant changes in GDP. An analysis of tax dynamics in real terms (Figure A5) suggests that the high elasticities are driven by the drops in taxes that occurred during the economic crises of 20082009 and 2014. Import taxes fell due to the rapid currency depreciation that accompanied the crises and caused sharp drops in imports. ${ }^{15}$ Another contributor to the decline in import tariffs receipts was Ukraine's accession to the World Trade Organization (WTO). The corporate income tax also demonstrates strong respond to declines in GDP, especially after the 2014 crisis. To remove the effect of depreciation on import taxes, we specified ARDL models in line with the algorithm (10), which was used for estimating the coefficients in Table B4. As variables, we used seasonally adjusted nominal GDP, VAT on imports and import tariffs denominated in US dollars basing on the official nominal exchange rate. The resulting elasticities are significantly lower. For VAT on imports, the long-term elasticity equals 1.4 and the short-term elasticity is 1.2. For the import tariffs, the elasticities are 0.66 and 0.7 respectively. ${ }^{16}$ Thus, the significant deviation of the import tax elasticities for Ukraine from the same indicators for OECD countries is attributed to the periods of severe economic crises and depreciation, which are not typical for developed economies.

In line with the obtained results, we use the following values as elasticities to estimate fiscal stance: for budget revenues -1.2 , for PIT -0.7 , for VAT on imports -2.6 , for domestic VAT -1 , for CIT -1.8 , for the import tariffs -0.8 , and for the excise tax -0.7 . These are the average values of the long-term elasticities from Tables B4 and B5. For PIT and excise taxes, we use the short-term elasticity.
Table B5 also has the estimated elasticity of PFU deficit financing with respect to GDP. As the time series of the PFU deficit financing had an unspecified order of integration, we used the ARDL model to estimate the elasticities. Based on the results of the regression, the short-term elasticity of PFU deficit financing with respect to GDP stands at (-1.7).

Figure A6 (in Appendix A) shows the contributions of the budget components that we identified as cyclical to the gap between the primary budget deficit and the fiscal stance measure. ${ }^{17}$ For the sake of clarity, we also present a graph of the GDP gap. The biggest impact on the budget's cyclical component is made by VAT, because of the significant share of this tax in budget revenues and the high elasticity of VAT on imports with respect to GDP. The next biggest contributor to the budget's cyclical component is the corporate income tax. PFU deficit financing increases during economic downturns, widening the budget deficit and decreases in times of economic growth.

Figures $A 7$ and $A 8$ (in Appendix A) present the graphs of the fiscal stance and fiscal impulse estimates for Ukraine obtained by using the approach described by equation (4) and the IMF methodology, the short version of which is expressed by equation (2). We present alternative estimates of the fiscal stance and the fiscal impulse to demonstrate the consistency of our approach. The IMF approach involves estimating the fiscal stance measure on the basis of relative budget indicators in the base year when the GDP gap was minimal. As a base year, we opted for 2004, when the GDP gap stood at $+0.2 \%$. To obtain quarterly estimates of the fiscal stance and the fiscal impulse, we used the annual estimates of $r_{o}$ and $g_{0}{ }^{18}$ To estimate the annual indicators, we applied the same $r_{0}$ and $g_{0}$ to the annual indicators of consolidated budget revenues and expenditures. To smooth out the movements in the indicators of fiscal stance and, hence, the fiscal impulse, we applied a moving average of the previous four quarters (Figures A9 and A10, in Appendix A). We then converted the calculations into annual data by computing the simple means for the four quarters of each year (Figures A11 and A12, in Appendix A).

Figures A8 and A9 show that the different estimates of fiscal stance yield similar dynamics in the indicators, although they differ in their levels. The informative episodes of the government's fiscal policy actions are the periods of 2006-2008 when the economy overheated as global commodity prices rose amid low-interest rates, and 2014-2015 when the severe economic crisis started (Figure A7). In 2006-2008, fiscal policy was becoming increasingly loose, up until the financial and economic crisis, which prompted the government to switch to a tight fiscal policy in 2009. A shift to fiscal policy tightening can also be seen in 2014, but in that year the consolidation was significantly greater than during the 2009 crisis. The loosening of fiscal policy in the second half of 2007 through 2008 is attributed to the fact that tax receipts did not grow in proportion to GDP, as evidenced by the estimated elasticities. The increase in the pri-

\footnotetext{
${ }^{15}$ The growth in the import tariffs in 2015 was the result of a temporary increase of the rates, which came after the 2014 crisis as part of the emergency measures taken to revitalize the economy.

${ }^{16} \mathrm{As}$ an alternative, we ran threshold regressions. As the threshold variable, we chose the first differences of the log of the nominal exchange rate against the US dollar (exch) with a lag that selected so as to minimize the total least squares of the model's errors. For VAT on imports, the threshold value came out at $t \_$exch $h_{t-1}=-0.008$, the elasticity below the threshold value amounted to $e<t_{-}$exch $h_{t-1}=1.7$, and the elasticity above the threshold value came in at $e>t_{-}$exch $=4.1$. For the import tariffs, the relevant indicators were $t_{-}$exch $t_{t-1}=0.006, e<t_{-}$exch $h_{t-1}=1.12$, and e>t_exch $h_{t-1}=2.5$. For CIT: $t_{-}$exch $h_{t-1}=0.006, e<t_{-} e x c h=0.8$, and $e>t_{-}$exch ${ }_{t-1-1}=4.7$. During the rapid currency depreciation that comes with economic crises, elasticities increase dramatically.

${ }^{17}$ The average values of the cyclical components of taxes in relation to potential GDP for $2004-2016$ are: $0.81 \%$ for VAT, 0.21\% for CIT, 0.11\% for IIT, 0.08\% for excise taxes, $0.07 \%$ for PFU deficit financing, and $0.03 \%$ for the import tariffs.

${ }^{18}$ The ratio of budget revenues to nominal GDP in the base year and the ratio of primary budget expenditures to nominal GDP in the base year, respectively.
} 
mary deficit of the consolidated budget in 2009 was driven by the economic downturn, but the cyclically adjusted budget balance points to a tighter fiscal policy. The 2014 crisis led to a point at which the budget's cyclical component became negative (the fall in GDP triggered an automatic drop in tax receipts, inflating the budget deficit). As a result, the fiscal stance measure indicates an even tighter fiscal policy than does the primary budget balance. The tight fiscal policy episodes were seen in the second half of 2014, and especially in 2015, coinciding with the budget cuts of 2014 and the fiscal consolidation of 2015. There was a certain easing of the policy in 2016 compared to the previous two years. Apart from the episodes noted above, the graphs of the annual data indicate a fiscal policy easing in 2010 , driven by presidential elections, a tightening of the policy in 2011, and another easing in 2012, which could be the result of Ukraine hosting the 2012 European football championship.

The two fiscal impulse estimation approaches used in this paper yield similar results - which speaks for their robustness. When compared, the fiscal policy responses to the economic crises indicate that fiscal policy became significantly tighter following the 2014 crisis than during that of 2008 and 2009. The underlying reasons for such government actions are rooted in different scales and nature of the shocks appeared during those crises, and in the specifics of Ukraine's fiscal policy reaction function, which only switches into active (countercyclical) regime when public debt grows to high levels and the GDP gap becomes positive (Vdovychenko, 2017). The tightening of fiscal policy in Ukraine in 2014-2015 is explained by more serious geopolitical and structural consequences for Ukraine's economy compared to the fall in world commodity markets and the liquidity crunch of 2008 , as well as by a protracted period of procyclical fiscal policy and a significant accumulation of public debt since the 2008-2009 crisis, including external public debt.

\section{DISCUSSION OF THE RESULTS AND CONCLUSIONS}

The use of methodologies that are similar to the OECD approach is commonplace when estimating the fiscal impulse. The OECD approach, which was somewhat modified to allow for its application to the case of Ukraine, identifies periods of tight and loose fiscal policy. The use of the OECD disaggregation approach identifies the budget items that are the most important for generating the cyclical component of the fiscal balance. In Ukraine, the strongest cyclical impact on the budget comes from the VAT and the corporate income tax.

The dynamics of the estimated fiscal stance (and the fiscal impulse respectively), indicates that the government's responses to the economic crises of 2008-2009 and 2014 in the fiscal policy context were radically different. In reacting to the 2008-2009 crisis, for instance, the government had to reduce the budget deficit somewhat, but its fiscal policy remained close to neutral and became loose in 2010. This is attributed to the raft of tax benefits that the government enacted to support the economy as it went through the crisis (introducing a special VAT regime for agricultural producers, in particular), as well as to the presidential elections of 2010. The 2014 crisis resulted in a substantial consolidation of the budget and in a tightening of fiscal policy (among other things, by raising interest rates and levying PIT on passive income), which is explained by the large public debt that had been accumulated by that time.

The elasticities of taxes on imports and CIT with respect to GDP are rather high due to their asymmetric response to fluctuations in GDP in periods of economic growth and crises. The elasticity of PIT with respect to GDP is slightly lower than that in developed economies, due to the absence of progressive taxation and a weak emphasis on taxing passive income. The elasticities of other tax receipts we have estimated are in line with the analogous measures for OECD countries.

To test the robustness of the OECD approach used in this study, we estimated the fiscal impulse under the IMF methodology. Both approaches yield results that are similar in value. 


\section{REFERENCES}

- Bornhorst F., Dobrescu G., Fedelino A., Gottschalk J., and Nakata T. (2011). When and How to Adjust Beyond the Business Cycle? A Guide to Structural Fiscal Balances. IMF Technical Notes and Manuals, No. 2011/02

- Bouthevillain C., Cour-Thimann P., van den Dool G., Hernandez De Cos P., Langenus G., Mohr M., Momogliano S., Tujula M. (2001). Cyclically-adjusted Budget Balances: An Alternative Approach. ECB Working Paper Series, No. 77.

- Dudine P., Jalles, J. T. (2017). How Buoyant is the Tax System? New Evidence from a Large Heterogeneous Panel. IMF Working Papers, No. 17/4.

- Engle R., Granger C. (1987). Cointegration and Error Correction: Representation, Estimation and Testing. Econometrica, Vol. 55, No. 2, pp. 251-276.

- Fatás A., Mihov I. (2009). Why Fiscal Stimulus is Likely to Work. International Finance, Vol. 12, No. 1, pp. 57-73. https://doi.org/10.1111/j.1468-2362.2009.01235.x

- Gali J., Perotti R. (2003). Fiscal Policy and Monetary Integration in Europe. Economic Policy, Vol. 18, No. 37, pp. 533-572.

- Girouard N., André C. (2005), Measuring Cyclicallyadjusted Budget Balances for OECD Countries. OECD Economics Department Working Papers, No. 434.

- Heller P. S., Haas R. D., Mansur A. S. (1986). A Review of the Fiscal Impulse Measure. IMF Occasional Paper, No. 44.

- Koester G. B., Priesmeier C. (2012). Estimating Dynamic Tax Revenue Elasticities for Germany. Deutsche Bundesbank Discussion Paper, No. 23.

- Larch M., Turrini A. (2009). The Cyclically-Adjusted Budget Balance in EU Fiscal Policy Making: A Love at First Sight Turned Into a Mature Relationship. European Commission Economic Papers, No. 374.
- Masih A., Masih R. (1999). Are Asian Stock Market Fluctuations Due Mainly to Intra-Regional Contagion Effects? Evidence Based on Asian Emerging Stock Markets. PacificBasin Finance Journal, Vol. 7, No. 3-4, pp. 251-282.

- Narayan P. K. (2005). The Saving and Investment Nexus for China: Evidence from Cointegration Tests. Applied Economics, Vol. 37, No. 17, pp. 1979-1990. https://doi.org/10.1080/00036840500278103

- NBU (2016). Estimating the Potential GDP and the Cyclic Position of the Ukrainian Economy. In: Inflation Report. July, pp. 22-23.

- Nikolaichuk S., Mariiko Y. (2007). Determination of Equilibrium and Cyclic Components of Macroeconomic Indicators Using the Kalman Filter. Visnyk of the National Bank of Ukraine, No. 5, pp. 58-64.

- Pesaran M. H., Smith R. J., Shin Y. (2001). Bounds Testing Approaches to the Analysis of Level Relationships. Journal of Applied Econometrics, Vol. 16, No. 3, pp. 289-326. https://doi.org/10.1002/jae.616

- Phillips P. C. B., Hansen B. E. (1990). Statistical Inference in Instrumental Variables Regressions with I(1) Processes. Review of Economic Studies. Vol. 57, No. 1, pp. 99-125.

- Schinasi G. J., Lutz M. S. (1991). Fiscal impulse. IMF Working Paper, No. 91/91.

- Stock J., Watson M. (1993). A Simple Estimator of Cointegrating Vectors in Higher Order Integrated Systems. Econometrica, Vol. 61, No. 4, pp. 783-820.

- van den Noord P. (2000). The Size and Role of Automatic Fiscal Stabilizers in the 1990s and Beyond. OECD Working Paper, No. 230.

- Vdovychenko A. (2017). Fiscal Policy Reaction Function and Sustainability of Fiscal Policy in Ukraine. Visnyk of the National Bank of Ukraine, No. 240, pp.22-35. https://doi.org/10.26531/vnbu2017.240.022 


\section{APPENDIX A. FIGURES}

Figure A1. Nominal and Primary Balance

of the Consolidated Budget of Ukraine, \% GDP

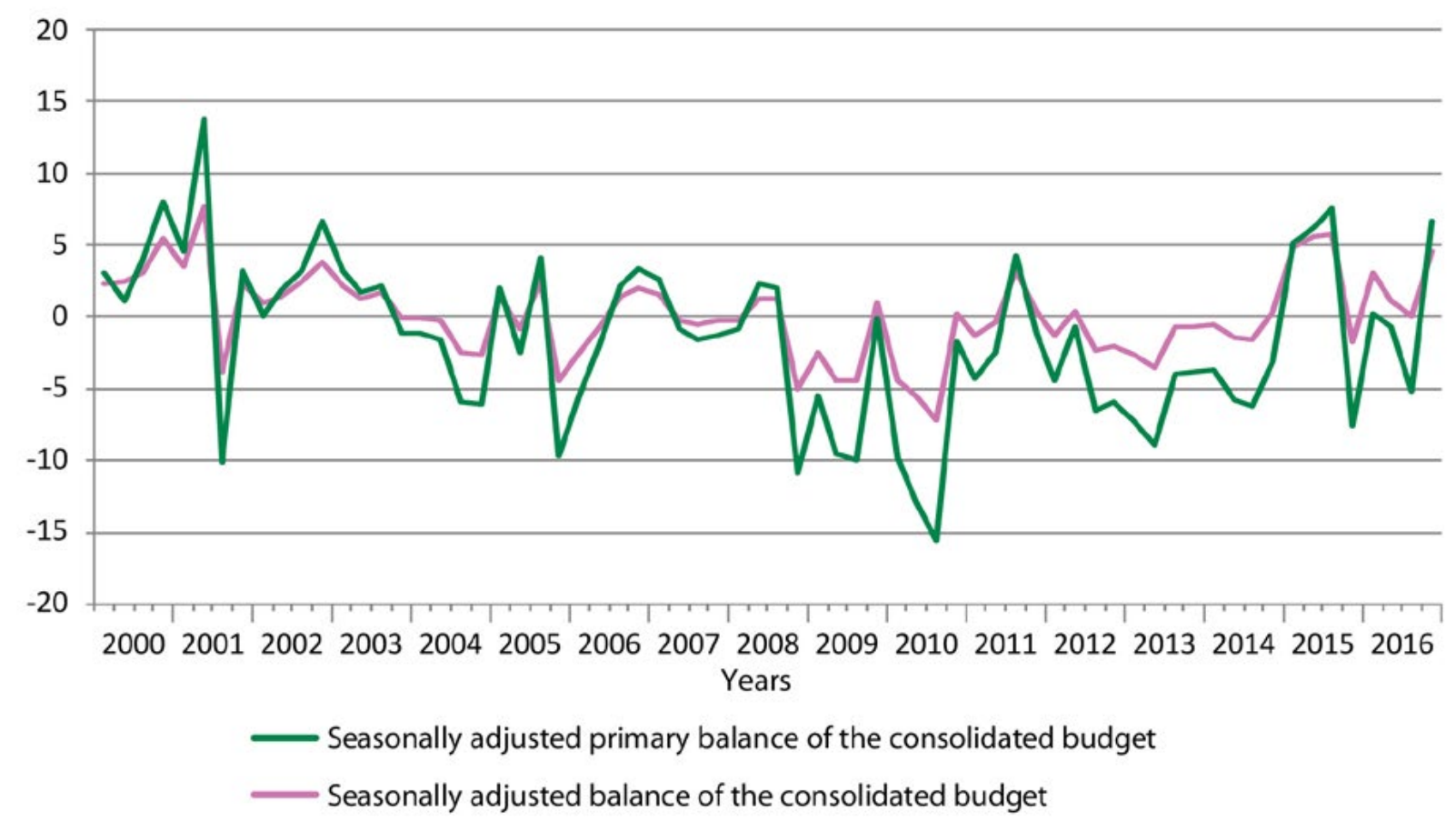

Figure A2. Tax Receipts in Ukraine, \% GDP

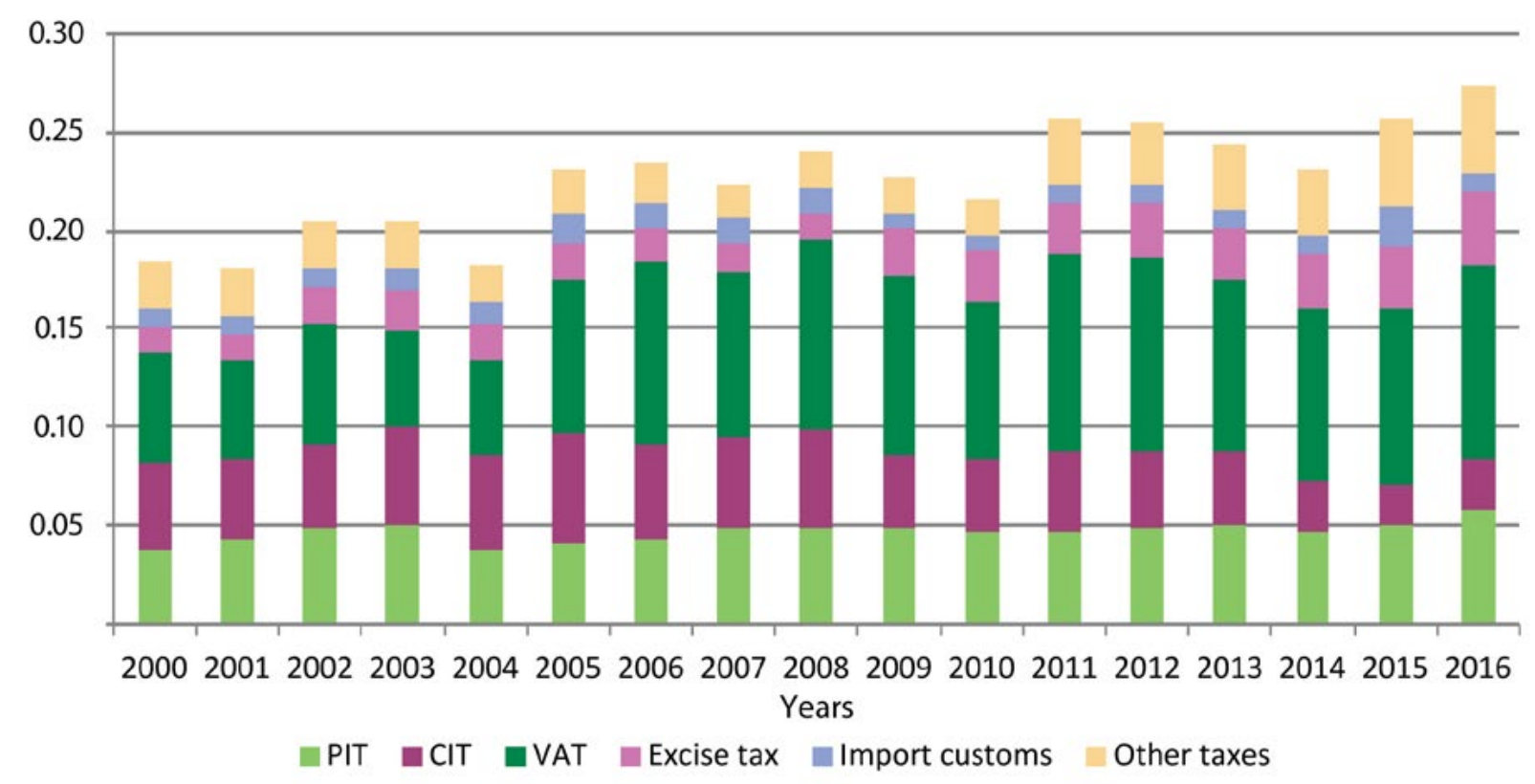


Figure A3. Marginal Tax Rates of CIT and PIT in Ukraine, \%

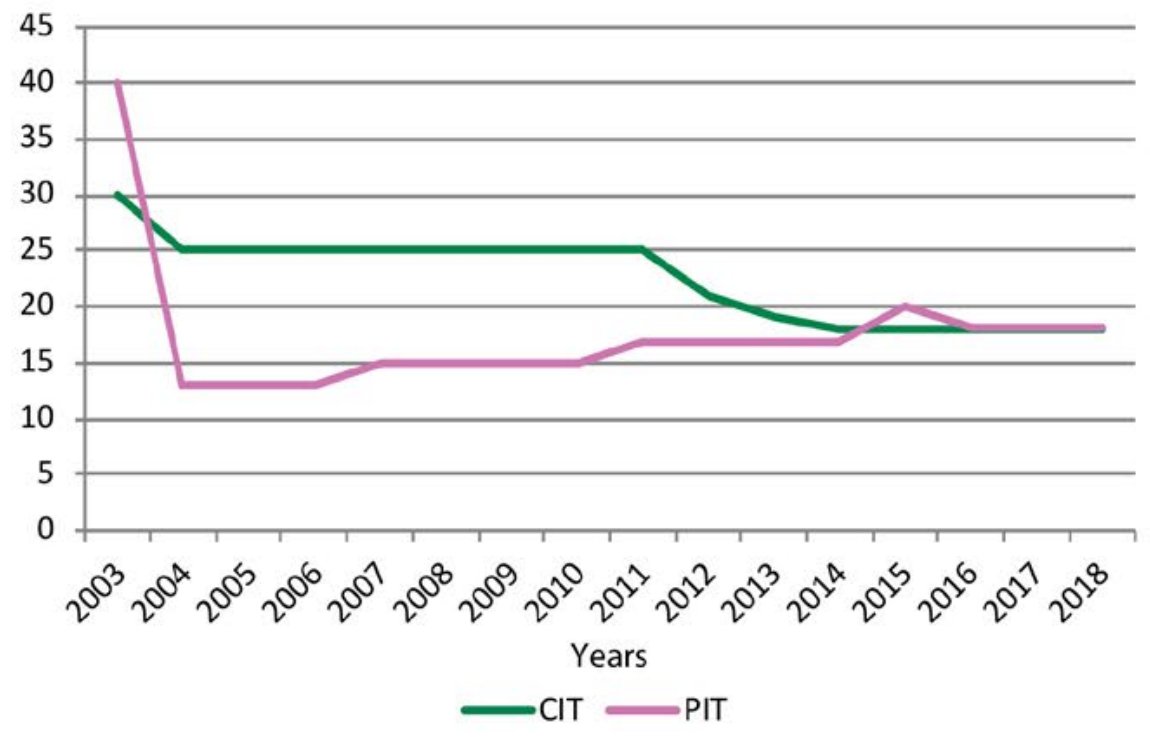

Figure A4. Excise Tax and PFU Deficit Financing with Structural Breaks
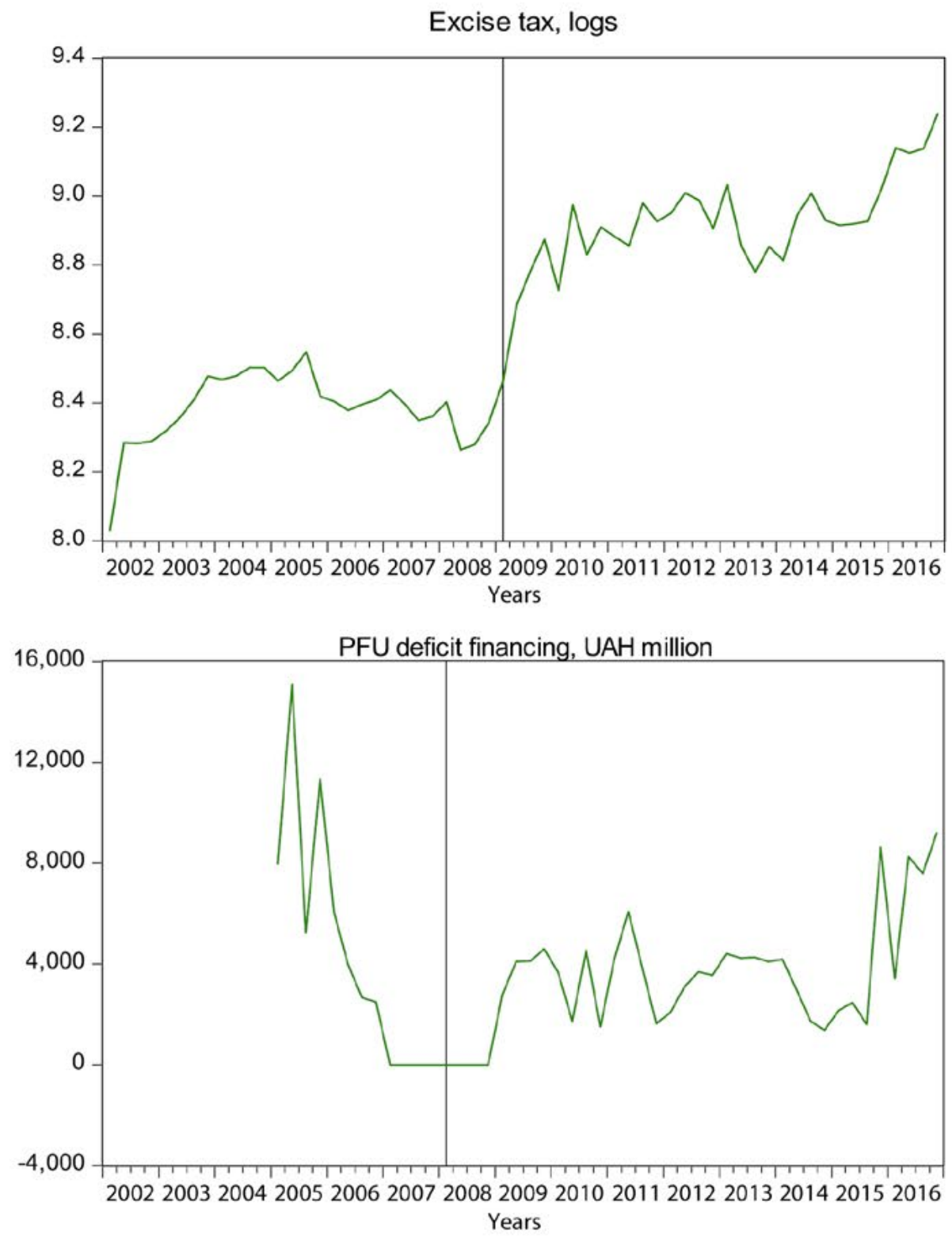
Figure A5. Seasonally Adjusted Real GDP

and Certain Taxes (Logs), 2002-2016
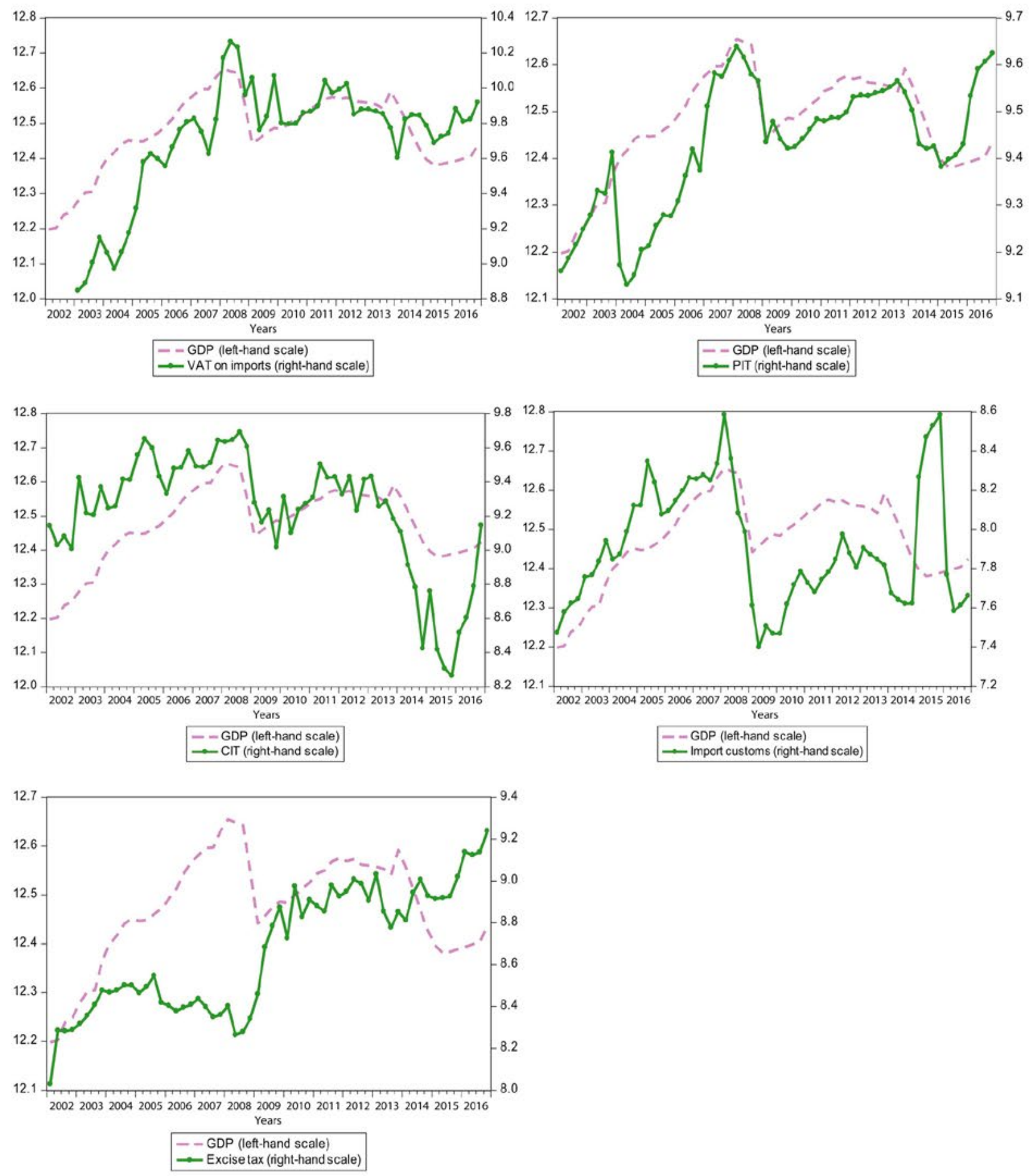
Figure A6. Contributions of Budget Categories to the Cyclical Fiscal Balance

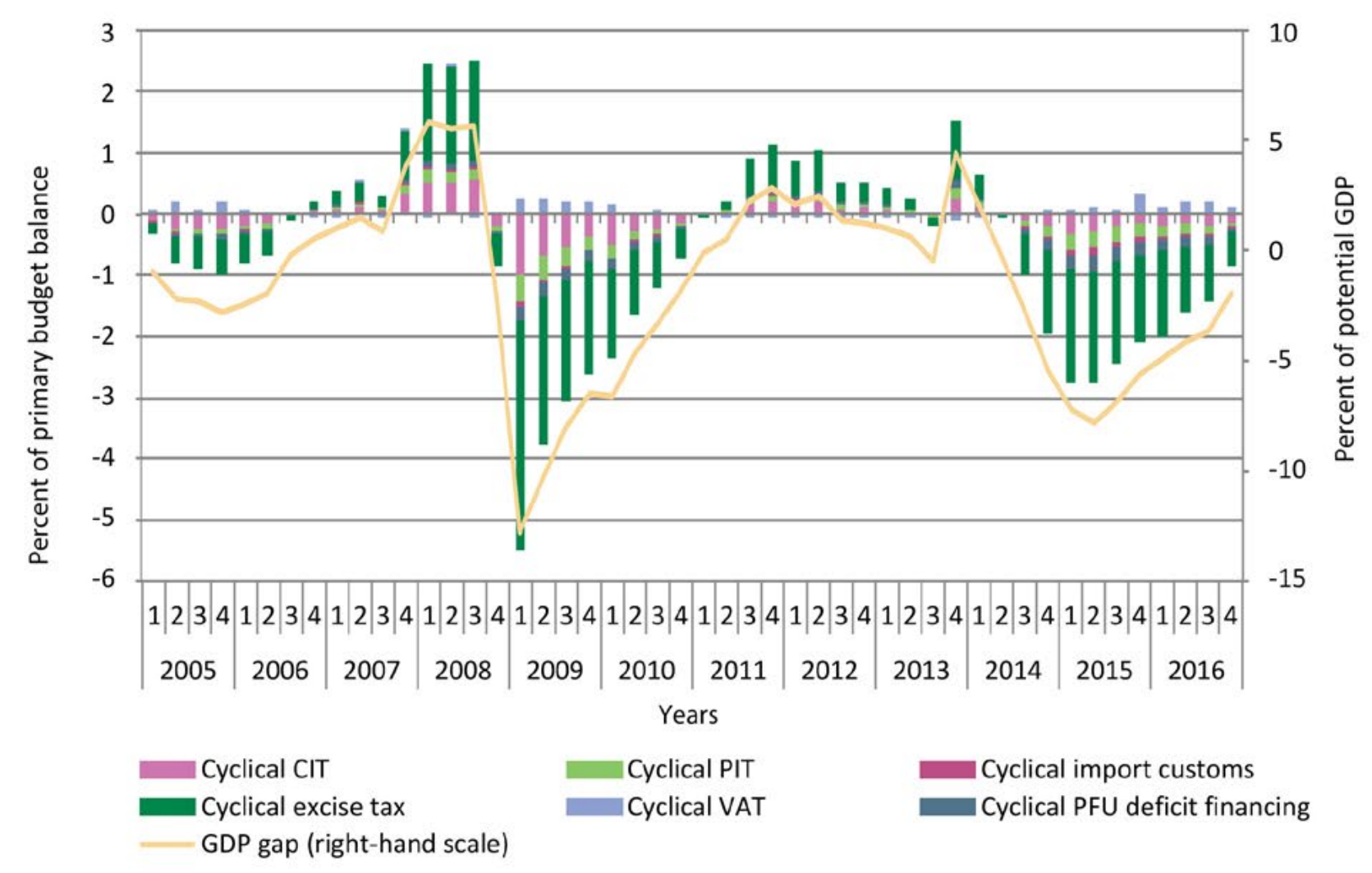

Figure A7. Fiscal Stance and Primary Budget Balance, $\%$ of Seasonally Adjusted Real GDP

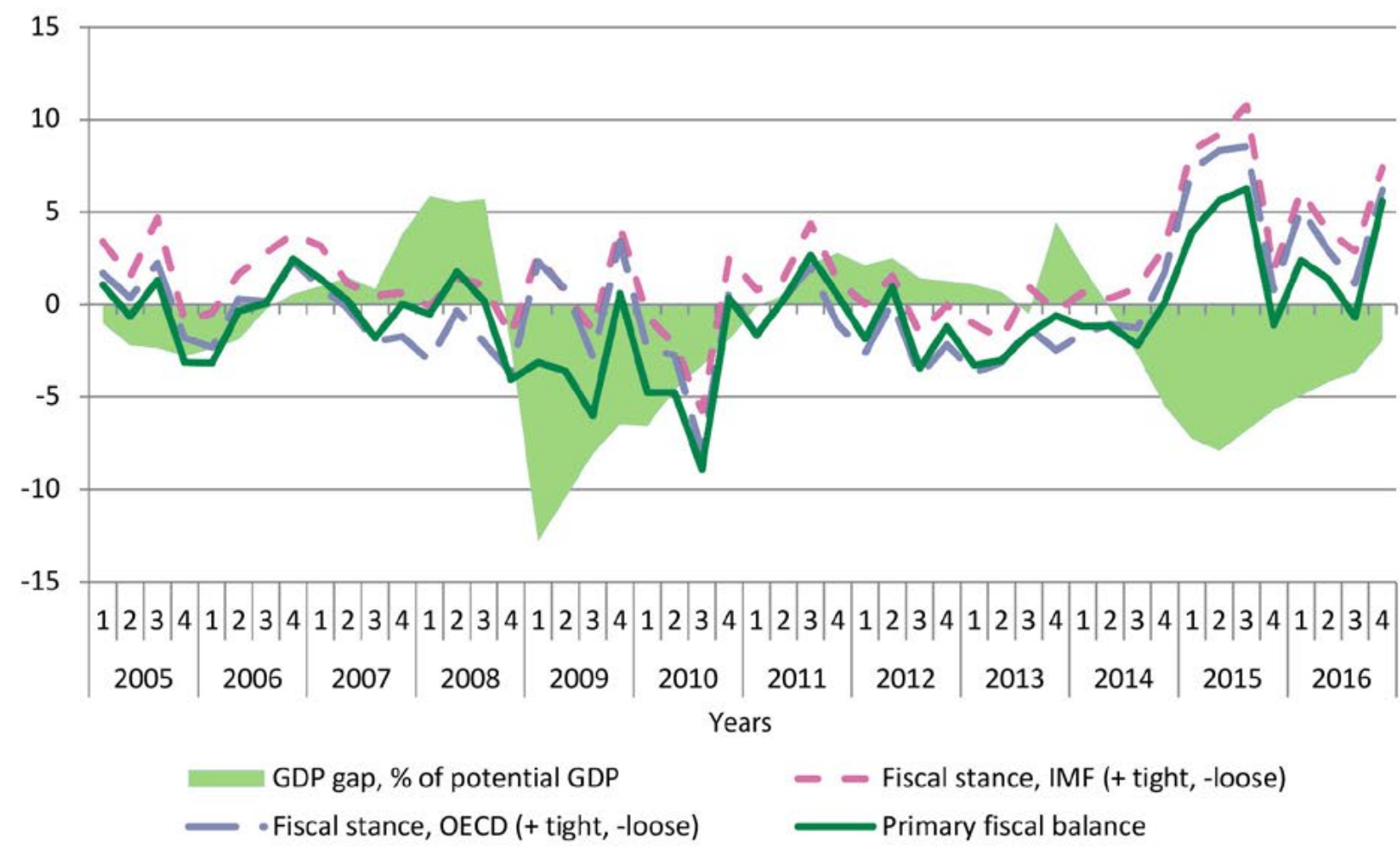


Figure A8. Fiscal Impulse, \% of Seasonally Adjusted Real GDP

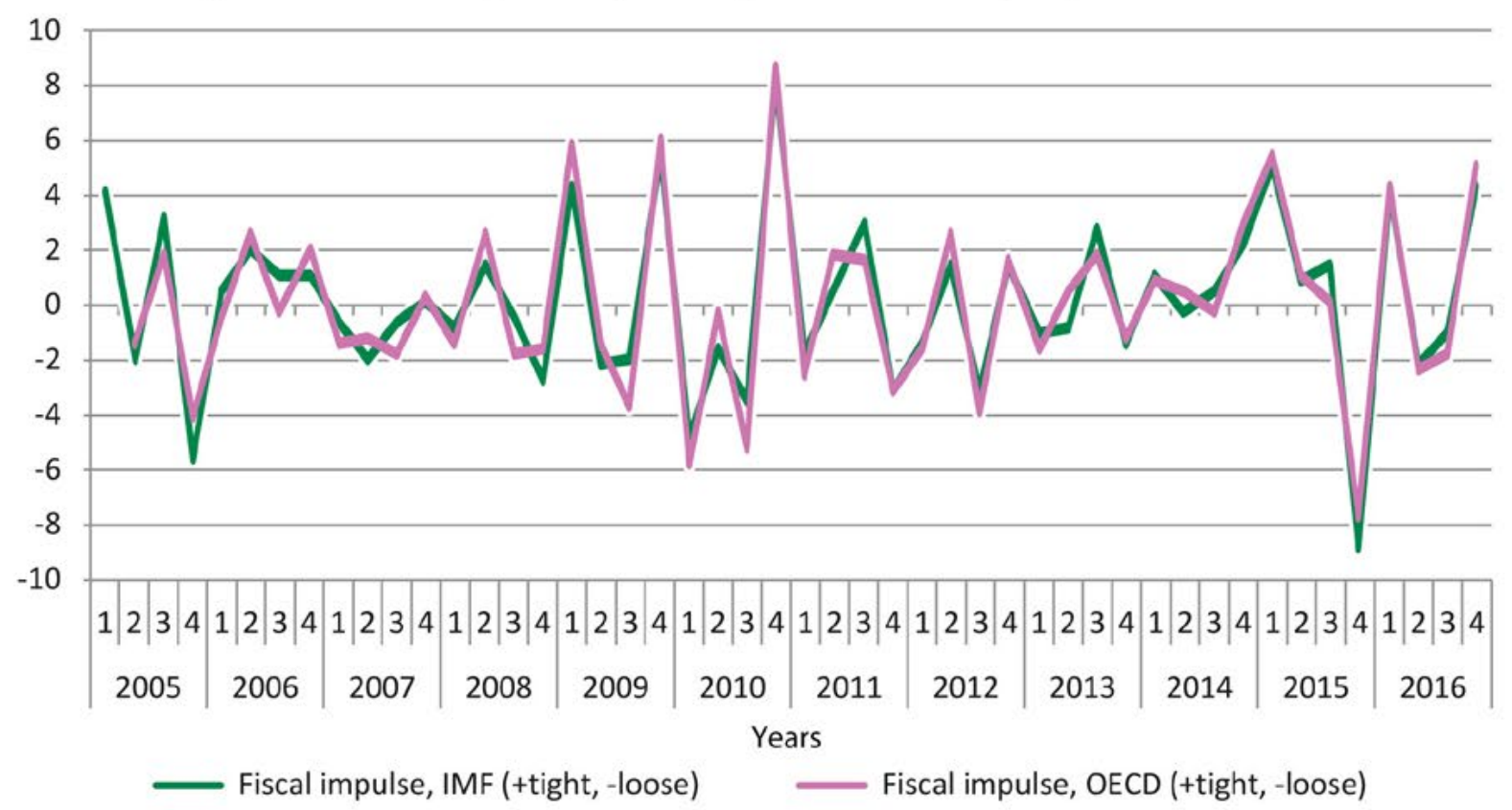

Figure A9. Moving Average of Fiscal Stance, $\%$ of Seasonally Adjusted Real GDP

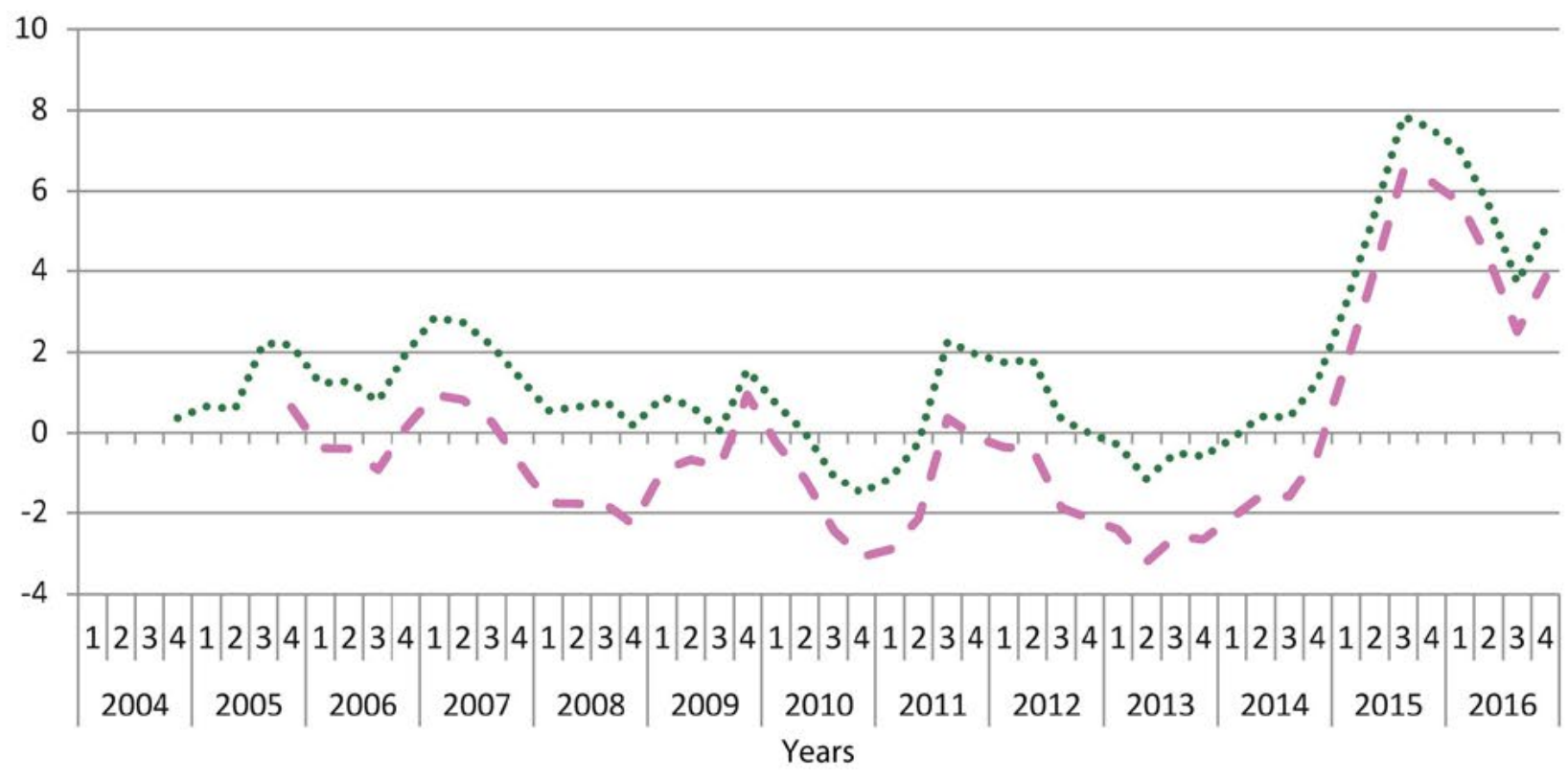

...... Fiscal stance moving average, IMF (+tight, -loose)

- Fiscal stance moving average, OECD (+tight, -loose) 
Figure A10. Fiscal Impulse Dynamics, \% of Seasonally Adjusted Real GDP

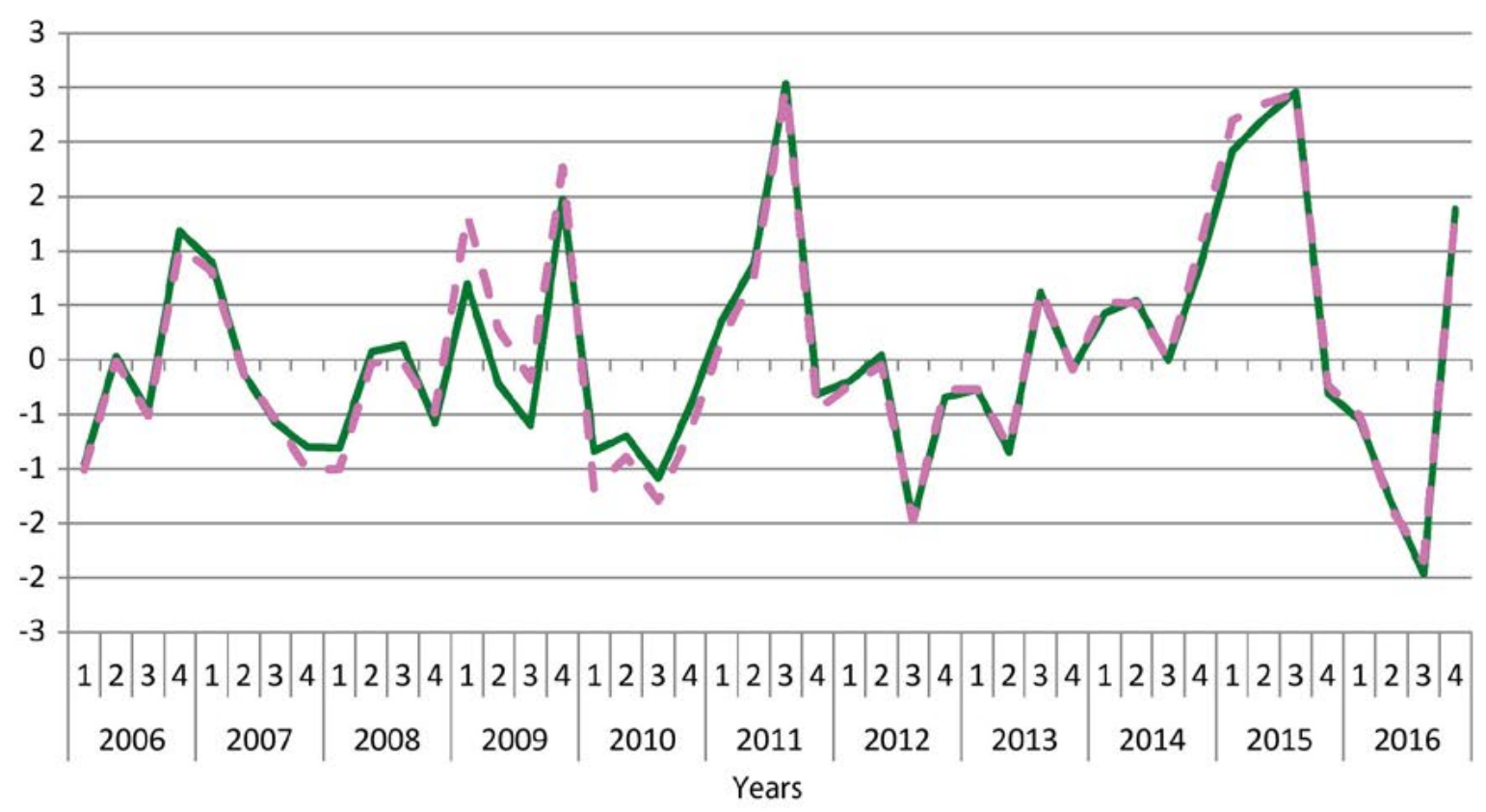

_Fiscal impulse moving average, IMF (+tight, -loose)

- Fiscal impulse moving average, OECD (+tight, -loose)

Figure A11. Annual Fiscal Stance, \% of Real GDP

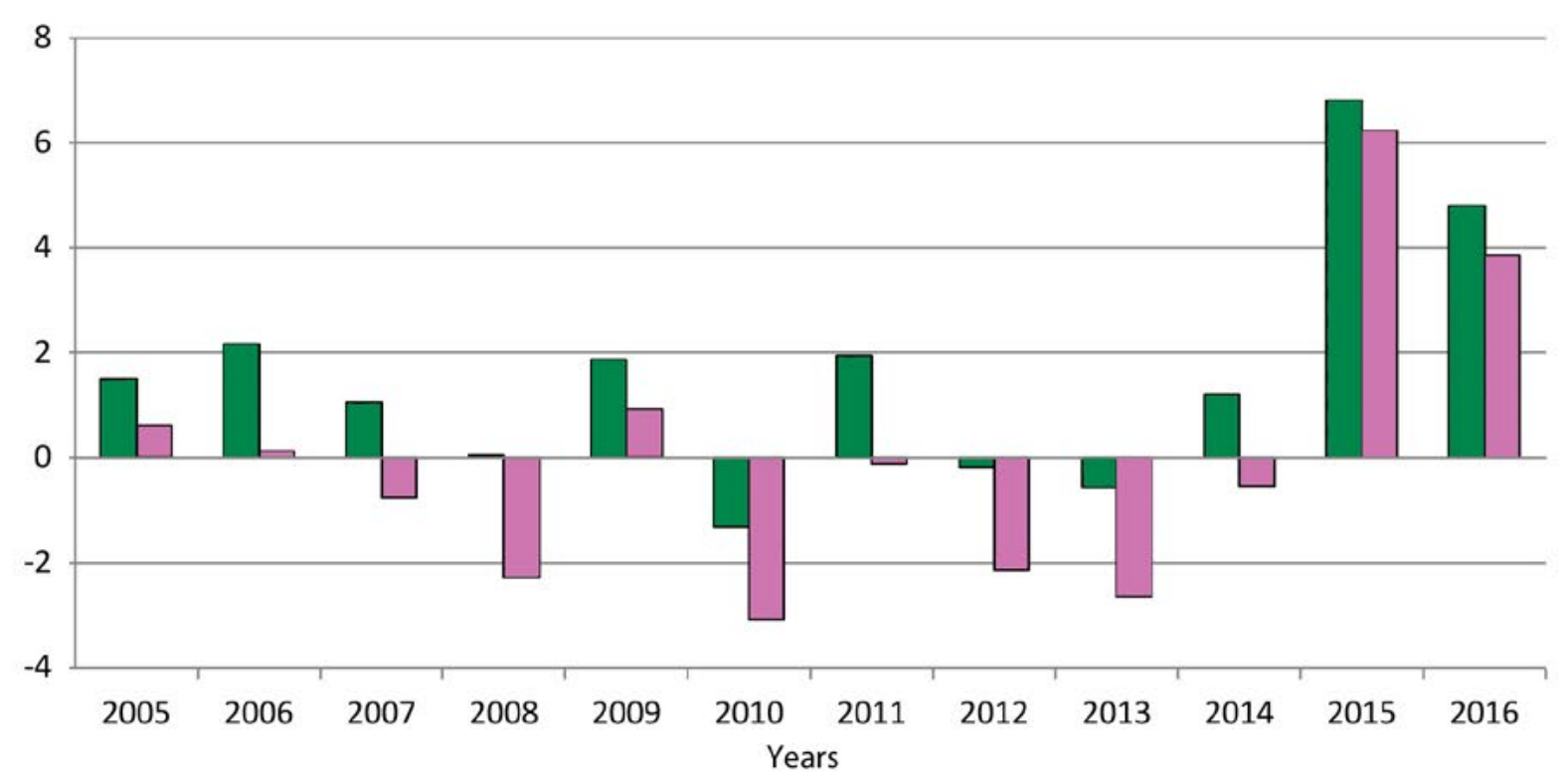

$\square$ Fiscal stance, IMF (+tight, -loose) $\quad \square$ Fiscal stance, OECD (+tight, -loose) 
Figure A12. Annual Fiscal Impulse, \% of Real GDP

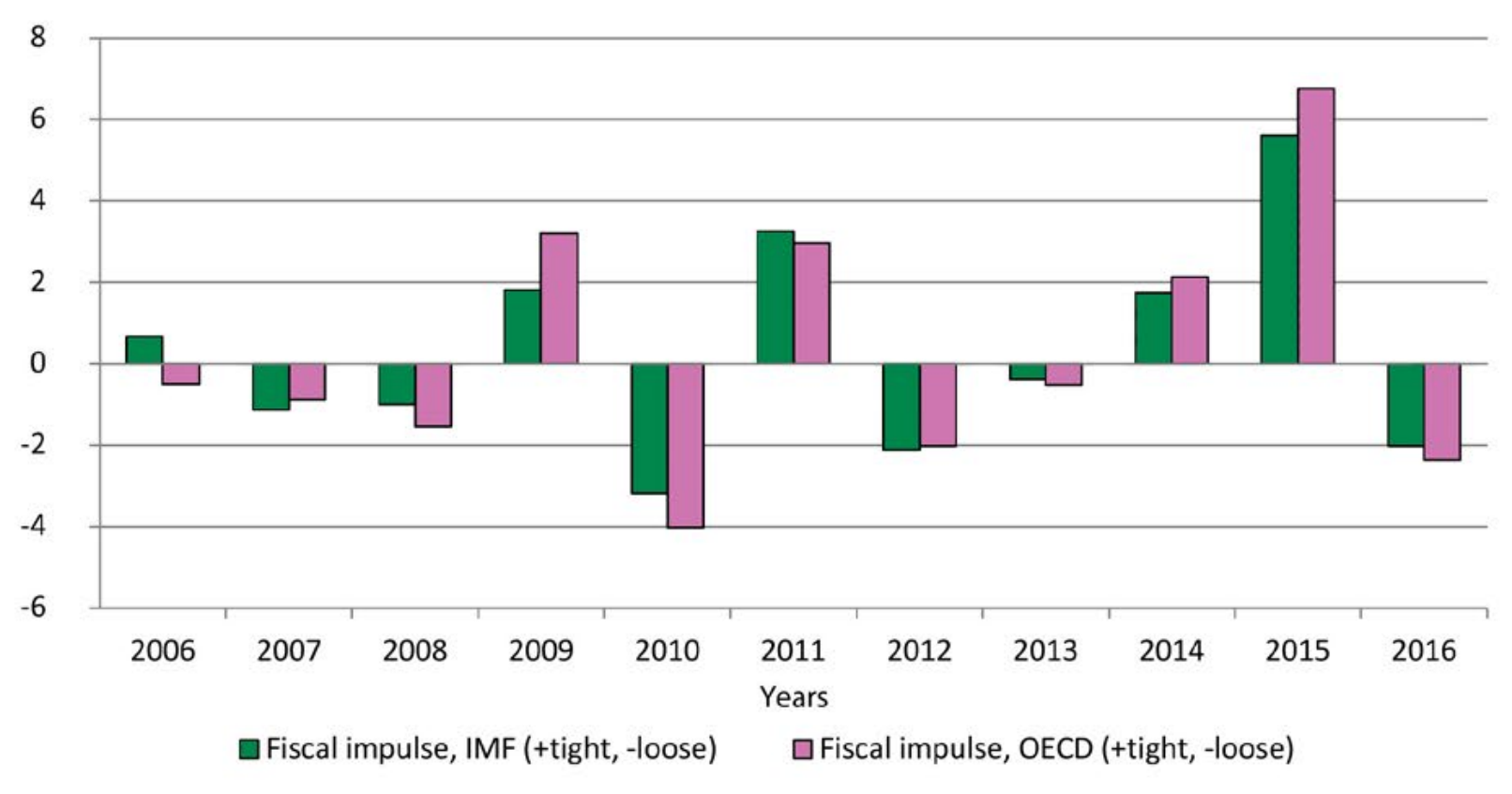


APPENDIX B. TABLES

Table B1. Descriptive Statistics of Variables, Natural Logs

\begin{tabular}{|c|c|c|c|c|c|c|c|c|}
\hline Indicators & PIT & CIT & $\begin{array}{l}\text { VAT on } \\
\text { imports }\end{array}$ & $\begin{array}{c}\text { Domestic } \\
\text { VAT }\end{array}$ & $\begin{array}{l}\text { Import } \\
\text { tariffs }\end{array}$ & $\begin{array}{c}\text { Excise } \\
\text { tax }\end{array}$ & GDP & $\begin{array}{l}\text { PFU deficit } \\
\text { financing, } \\
\text { UAH } \\
\text { million }\end{array}$ \\
\hline Mean & 9.45 & 9.23 & 9.77 & 9.58 & 7.94 & 8.72 & 12.51 & $3,771.00$ \\
\hline Median & 9.48 & 9.31 & 9.82 & 9.60 & 7.87 & 8.82 & 12.51 & $3,709.91$ \\
\hline Maximum & 9.64 & 9.69 & 10.26 & 9.82 & 8.58 & 9.24 & 12.65 & $15,064.44$ \\
\hline Minimum & 9.13 & 8.26 & 8.97 & 9.23 & 7.40 & 8.26 & 12.38 & 0.00 \\
\hline $\begin{array}{l}\text { Standard } \\
\text { Deviation }\end{array}$ & 0.13 & 0.37 & 0.27 & 0.12 & 0.31 & 0.28 & 0.08 & 3,129.38 \\
\hline Skewness & -0.84 & -1.17 & -1.24 & -0.46 & 0.34 & -0.12 & 0.03 & 1.34 \\
\hline Kurtosis & 3.02 & 3.53 & 5.03 & 2.93 & 2.15 & 1.61 & 1.99 & 5.32 \\
\hline Jarque-Bera & 6.11 & 12.36 & 22.18 & 1.81 & 2.58 & 4.33 & 2.22 & 25.06 \\
\hline Probability & 0.05 & 0.00 & 0.00 & 0.40 & 0.27 & 0.11 & 0.33 & 0.00 \\
\hline Observations & 52 & 52 & 52 & 52 & 52 & 52 & 52 & 48 \\
\hline
\end{tabular}

Table B2. Stationarity Tests of Real GDP and Various Budget Categories in Ukraine

\begin{tabular}{|c|c|c|c|c|c|c|c|c|c|c|}
\hline & $\begin{array}{c}\text { Time series } \\
\text { stationarity test }\end{array}$ & $\begin{array}{l}\text { Real } \\
\text { GDP }\end{array}$ & $\begin{array}{l}\text { Budget } \\
\text { revenues }\end{array}$ & PIT & $\begin{array}{l}\text { VAT on } \\
\text { imports }\end{array}$ & $\begin{array}{l}\text { Domestic } \\
\text { VAT }\end{array}$ & CIT & $\begin{array}{l}\text { Import } \\
\text { tariffs }\end{array}$ & $\begin{array}{c}\text { Excise } \\
\operatorname{tax}\end{array}$ & $\begin{array}{c}\text { PFU } \\
\text { deficit } \\
\text { financing }\end{array}$ \\
\hline \multirow{2}{*}{$\frac{n}{0}$} & $\begin{array}{l}\text { Dickey-Fuller GLS, } \\
\text { t-statistic }\end{array}$ & -0.95 & -0.90 & -0.40 & -0.76 & -1.40 & -1.60 & -0.92 & 0.27 & -1.78 \\
\hline & $\begin{array}{l}\text { KPSS, } \\
\text { LM-statistics }\end{array}$ & 0.30 & $0.43^{* *}$ & $0.64^{* *}$ & $0.54^{* *}$ & 0.25 & $0.44^{* *}$ & 0.11 & $0.87^{* *}$ & $0.12^{* *}$ \\
\hline \multirow{2}{*}{ 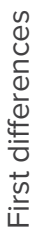 } & $\begin{array}{l}\text { Dickey-Fuller GLS, } \\
\text { t-statistic }\end{array}$ & $-4.05^{* *}$ & $-7.80^{* *}$ & $-7.10^{* *}$ & $-7.07^{* *}$ & $-4.60^{* *}$ & $-3.90^{* *}$ & $-2.37^{* *}$ & -1.75 & $-1.12^{* *}$ \\
\hline & $\begin{array}{l}\text { KPSS, } \\
\text { LM-statistics }\end{array}$ & 0.36 & 0.11 & 0.10 & 0.31 & 0.09 & 0.18 & 0.10 & 0.13 & 0.23 \\
\hline
\end{tabular}

The null hypothesis under Dickey-Fuller GLS is the presence of a unit root; the null hypothesis under KPSS is the absence of a unit root;

${ }^{* *}$ the level of significance of the null hypothesis is $5 \%$. 


\section{Table B3. Elasticities of Individual Consolidated Budget Items with Respect to GDP for Ukraine and OECD Countries}

\begin{tabular}{|c|c|c|c|c|c|}
\hline \multirow[t]{2}{*}{ Variables } & \multicolumn{2}{|c|}{$\begin{array}{l}\text { DOLS estimates } \\
\text { for Ukraine }\end{array}$} & \multicolumn{2}{|c|}{$\begin{array}{l}\text { ARDL estimates } \\
\text { for Ukraine }\end{array}$} & \multirow{2}{*}{$\begin{array}{l}\text { Average estimates } \\
\text { for OECD countries } \\
\text { (Average elasticity) }\end{array}$} \\
\hline & $\left(\beta^{19}\right)$ & $\left(\alpha^{20}\right)$ & $(\beta)$ & $(\alpha)$ & \\
\hline Budget revenues & $1.2^{* * *}$ & $0.7^{* * *}$ & $1.2^{* * *}$ & $0.6^{* * *}$ & \\
\hline PIT & $0.9^{* * *}$ & $0.7^{* * *}$ & & $0.7^{* * * 21}$ & 1.3 \\
\hline VAT on imports & $2.7^{* * *}$ & $1.2^{* * *}$ & $2.5^{* * *}$ & 1.0 & $1.0^{22}$ \\
\hline Domestic VAT & $1.2^{* * *}$ & $1.2^{* * *}$ & $0.7^{* * *}$ & $1.0^{* * *}$ & 1.0 \\
\hline CIT & $1.7^{* * *}$ & $1.6^{* * *}$ & $1.9^{* * *}$ & $1.5^{* * *}$ & 1.5 \\
\hline Import tariffs & 0.9 & $1.7^{* * *}$ & $0.8^{* * *}$ & $1.7^{* * *}$ & 1.0 \\
\hline Excise tax & 0.6 & $0.7^{*}$ & & $0.7^{*}$ & 1.0 \\
\hline PFU deficit financing & & & & $-1.7^{*}$ & \\
\hline
\end{tabular}

\section{Table B4. DOLS Estimates of the Elasticities of Budget Categories with Respect to Real GDP}

\begin{tabular}{|c|c|c|c|c|c|c|c|}
\hline Variables & $\begin{array}{l}\text { Budget } \\
\text { revenues }\end{array}$ & PIT & $\begin{array}{l}\text { VAT on } \\
\text { imports }\end{array}$ & $\begin{array}{l}\text { Domestic } \\
\text { VAT }\end{array}$ & CIT & $\begin{array}{l}\text { Import } \\
\text { tariff }\end{array}$ & Excise tax \\
\hline$\beta$ & $1.2^{* * *}$ & $0.9^{* * *}$ & $2.7^{* * *}$ & $1.2^{* * *}$ & $1.7^{* * *}$ & 0.9 & 0.6 \\
\hline$\alpha$ & $0.7^{* * *}$ & $0.7^{* * *}$ & $1.2^{* * *}$ & $1.2^{* * *}$ & $1.6^{* * *}$ & $1.7^{* * *}$ & $0.7^{*}$ \\
\hline b & $-0.5^{* * *}$ & -0.03 & $-0.4^{* * *}$ & $-0.3^{* * *}$ & $-0.3^{* * *}$ & $-0.1^{* * *}$ & -0.1 \\
\hline $\begin{array}{l}\text { Engle-Granger test } \\
\text { (Engle-Granger z-statistic) }\end{array}$ & $-26.4^{* * *}$ & -2.2 & -8.1 & -13.6 & $(-8.4)$ & -6.1 & -2.4 \\
\hline Jarque-Bera test, $\left(\chi^{2}\right)$ & 1.6 & 3.4 & 1.1 & 2.5 & 1.6 & 0.3 & 0.9 \\
\hline $\begin{array}{l}\text { Breusch-Godfrey Serial Correlation } \\
\text { LM Test: }\left(4 \text { lags, }\left(\chi^{2}\right)\right)\end{array}$ & 2.6 & 3.2 & 4.6 & 2.4 & 3.3 & 6.3 & 7.5 \\
\hline
\end{tabular}

$\beta$ - long-term elasticity with respect to GDP; $\alpha$ - short-term elasticity with respect to GDP; $b$ - rate of convergence; ***the level of significance of the null hypothesis is $1 \%$; "*t the level of significance of the null hypothesis is $5 \%$; "the level of significance of the null hypothesis is $10 \%$. Engle-Granger test, H0: no time series cointegration. JarqueBera test, HO: the residuals are normally distributed. Breusch-Godfrey Serial Correlation LM Test, HO: no autocorrelation.

\footnotetext{
19 Long-term elasticity.

${ }^{20}$ Short-term elasticity.

${ }^{21}$ For the models in which the long-term relationship hypothesis was rejected, estimates are based on the first differences of the variables.

${ }^{22}$ For VAT on imports, domestic VAT, the import tariffs, and excise taxes, we present the assumed elasticity for indirect taxes.
} 
Table B5. ARDL Estimates of the Elasticities of Budget Categories with Respect to Real GDP

\begin{tabular}{|c|c|c|c|c|c|c|c|c|}
\hline Variables & $\begin{array}{l}\text { Budget } \\
\text { revenues }\end{array}$ & PIT & $\begin{array}{l}\text { VAT on } \\
\text { imports }\end{array}$ & $\begin{array}{c}\text { Domestic } \\
\text { VAT }\end{array}$ & CIT & $\begin{array}{l}\text { Import } \\
\text { tariff }\end{array}$ & Excise tax & $\begin{array}{c}\text { PFU } \\
\text { deficit } \\
\text { financing }\end{array}$ \\
\hline$\beta$ & $1.2^{* * *}$ & & $2.5^{* * *}$ & $0.7^{* * *}$ & $1.9^{* * *}$ & $0.8^{* * *}$ & & \\
\hline$\alpha$ & $0.6^{* * *}$ & $0.7^{* * * 23}$ & 1.0 & $1.0^{* * *}$ & $1.5^{* * *}$ & $1.7^{* * *}$ & $0.7^{*}$ & $-1.7^{*}$ \\
\hline b & $-0.5^{* * *}$ & & $-0.2^{* * *}$ & $-0.4^{* * *}$ & $-0.2^{* * *}$ & $-0.4^{* * *}$ & & \\
\hline Bounds Test, F-statistic & $11.7^{* *}$ & 4.0 & $5.4^{*}$ & $9.1^{* *}$ & $5.1^{*}$ & $26.0^{* *}$ & 1.2 & 3.5 \\
\hline Jarque-Bera test, $\left(\chi^{2}\right)$ & 0.2 & 2.4 & 3.1 & 0.1 & 1.7 & 0.7 & 0.4 & 0.2 \\
\hline $\begin{array}{l}\text { Breusch-Godfrey Serial } \\
\text { Correlation LM Test: } \\
\left(4 \text { lags, }\left(\chi^{2}\right)\right)\end{array}$ & 5.4 & 3.1 & 5.3 & 5.0 & 1.6 & 7.3 & 2.6 & 2.7 \\
\hline
\end{tabular}

$\beta$ - long-term elasticity with respect to GDP; $\alpha$ - short-term elasticity with respect to GDP; $b$ - rate of convergence; ${ }^{* * *}$ the level of significance of the null hypothesis is $1 \%$; "*the level of significance of the null hypothesis is $5 \%$; "the level of significance of the null hypothesis is $10 \%$. Bounds Test, H0: no long-term relationship. Jarque-Bera test, HO: the residuals are normally distributed. For Breusch-Godfrey Serial Correlation LM Test, HO: no autocorrelation.

\footnotetext{
${ }^{23}$ For models in which the long-term relationship hypothesis was rejected, model estimates of first differences of the variables are presented.
} 